Mini-review

\title{
Targeted inhibition of tumor proliferation, survival, and metastasis by pentacyclic triterpenoids: Potential role in prevention and therapy of cancer
}

\author{
Muthu K. Shanmugam ${ }^{\text {a }}$, An H. Nguyen ${ }^{\text {a }}$, Alan P. Kumar ${ }^{\text {a,b,c }}$, Benny K.H. Tan ${ }^{\text {a }}$, Gautam Sethi ${ }^{\text {a,b,* }}$ \\ ${ }^{a}$ Department of Pharmacology, Yong Loo Lin School of Medicine, National University of Singapore, Singapore 117597, Singapore \\ ${ }^{\mathrm{b}}$ Cancer Science Institute of Singapore, National University of Singapore, 28 Medical Drive, Singapore 117456, Singapore \\ 'School of Anatomy, Physiology, and Human Biology, The University of Western Australia, Crawley, Perth, Australia
}

\section{A R T I C L E I N F O}

\section{Article history:}

Received 5 December 2011

Received in revised form 28 February 2012

Accepted 29 February 2012

\section{Keywords:}

Cancer

Triterpenoids

Proliferation

Metastasis

Apoptosis

\begin{abstract}
A B S T R A C T
Over the last two decades, extensive research on plant-based medicinal compounds has revealed exciting and important pharmacological properties and activities of triterpenoids. Fruits, vegetables, cereals, pulses, herbs and medicinal plants are all considered to be biological sources of these triterpenoids, which have attracted great attention especially for their potent anti-inflammatory and anti-cancer activities. Published reports in the past have described the molecular mechanism(s) underlying the various biological activities of triterpenoids which range from inhibition of acute and chronic inflammation, inhibition of tumor cell proliferation, induction of apoptosis, suppression of angiogenesis and metastasis. However systematic analysis of various pharmacological properties of these important classes of compounds has not been done. In this review, we describe in detail the pre-clinical chemopreventive and therapeutic properties of selected triterpenoids that inhibit multiple intracellular signaling molecules and transcription factors involved in the initiation, progression and promotion of various cancers. Molecular targets modulated by these triterpenoids comprise, cytokines, chemokines, reactive oxygen intermediates, oncogenes, inflammatory enzymes such as COX-2, 5-LOX and MMPs, anti-apoptotic proteins, transcription factors such as NF- $\mathrm{KB}$, STAT3, AP-1, CREB, and Nrf2 (nuclear factor erythroid 2-related factor) that regulate tumor cell proliferation, transformation, survival, invasion, angiogenesis, metastasis, chemoresistance and radioresistance. Finally, this review also analyzes the potential role of novel synthetic triterpenoids identified recently which mimic natural triterpenoids in physical and chemical properties and are moving rapidly from bench to bedside research.
\end{abstract}

(c) 2012 Elsevier Ireland Ltd. All rights reserved.
Abbreviations: AML, acute myelogenous leukemia; ALL, acute lymphocytic leukemia; ATF2, activating transcription factor 2; ARE, antioxiant response element; ABCG2, ATP-binding cassette, sub-family G (WHITE), member 2; B-CLL, B-cell chronic lymphocytic leukemia; bZIP, basic leucine zipper; Bcl2, B-cell lymphoma 2; CLL, chronic lymphocytic leukemia; COX, cyclooxygenase; CREB, c-AMP response element binding protein; CDKN2, cyclin dependent kinase 2; DAPK1, death associated protein kinase 1; DR, death receptor; EGCG, (-)-epigallocatechin gallate; EGFR, epidermal growth factor receptor; FADD, Fas-associated protein with death

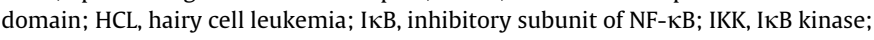
IL, interleukin; iNOS, inducible nitric oxide synthase; Keap1, Kelch-like ECHassociated protein 1; IAPs, inhibitor of apoptosis; LOX, lipoxygenase; MMP, matrix metalloproteinase, MAPK, mitogen-activated protein kinase; Nrf2, nuclear factorerythroid 2p45 (NF-E2)-related factor 2; NF- $\kappa B$, nuclear factor- $\kappa B$; PGC- $1 \alpha$, peroxisome proliferator activated receptor gamma coactivator 1 ; PARP, poly ADP ribose polymerase; ROS, reactive oxygen species; RNS, reactive nitrogen species; RCC, renal cell carcinoma; STAT3, signal transducer and activator of transcription 3; TRAMP, transgenic adenocarcinoma of prostate; TNF- $\alpha$, tumor necrosis factor; TGF$\beta$, transforming growth factor beta; TIMP-3, tissue inhibitor of metalloproteinase 3 ; VCAM-1, vascular cell adhesion molecule 1; VEGF, vascular endothelial growth factor.

* Corresponding author at: Department of Pharmacology, Yong Loo Lin School of Medicine, National University of Singapore, Singapore 117597, Singapore. Tel.: +65 65163267; fax: +65 68737690 .

E-mail address: phcgs@nus.edu.sg (G. Sethi).

\section{Introduction}

Medicinal plant-based traditional system of medicine commonly known as Ayurvedic medicine in India and traditional Chinese medicine have been the primary source of medication for centuries in the Asian subcontinent [1]. These natural remedies play an important role both in the prevention of development and in the treatment of chronic inflammation-driven diseases [2]. Numerous reports published within the last three decades have indicated that persistent inflammation is the primary initiating factor that causes major chronic diseases, while a comprehensive strategy towards prevention or treatment of these diseases is still lagging [3]. The discovery of various pathophysiological factors such as oncogenes, tumor suppressor genes, gene-specific mutations, cytokines, chemokines, growth factors and their receptors, intracellular signaling molecules, protein kinases, epigenetic makeup of the cell, the environmental factors, and finally the overall advancement in the development of technology-based genomics, proteomics and metabolomics contributes tremendously to our understanding of what is inflammation, what causes progression 
of chronic inflammation to cancer [4]. An urgent need to understand the various factors that contribute to and accelerate disease progression to an irreversible chronic stage need to be tackled with a variety of combined approaches [4,5]. Extensive research from our laboratory and that of others have provided ample evidence that bioactive phytochemicals present in spices, fruits, seeds, and cruciferous vegetables have shown the potential to prevent inflammation-driven diseases [3,6-8]. Overwhelming evidence also suggests that consumption of fruits, vegetables and medicinal plants rich in triterpenoids have shown beneficial effects against a variety of inflammation-driven diseases, including cancer of the breast, prostate, colon, lung, liver, kidney and the pancreas [2,9].

Terpenoids represents a large class of natural compounds which are classified according to the number of isoprene units [10]. Triterpenoids are synthesized in plants by cyclization of squalene and are major constituents in medicinal plant decoctions and extracts [10]. To date, approximately 20,000 triterpenoids have been identified from the various parts of medicinal plants [11]. The tetracyclic triterpenoid compound, tirucallic acid, has eight isoprene units while the majority of triterpenoids have six isoprene units. Tirucallic acid represents a new class of tetracyclic compounds that has been shown to induce apoptosis in prostate cancer cells with in vitro and in vivo. [12]. Other naturally occurring tetracyclic triterpenoids that show potent anti-inflammatory and anticancer activity include cucurbitacins, diosgenin, ganoderic acid, ginsenosides, gypenoside, oleandrin, and withanolide. However, among all the terpenoids, pentacyclic triterpenoids are the most potent natural product compounds showing wide ranging anti-inflammatory and anticancer activities and have been extensively studied. Naturally occurring pentacyclic triterpenoids include ursolic acid (UA), oleanolic acid (OA), betulinic acid (BetA), bosewellic acid
(BA), Asiatic acid (AA), $\alpha$-amyrin, celastrol, glycyrrhizin, 18 - $\beta$-glycyrrhetinic acid, lupeol, escin, madecassic acid, momordin I, platycodon D, pristimerin, saikosaponins, soyasapogenol B, and avicin [10,13] (Fig. 1). Recent development of synthetic pentacyclic triterpenoids viz. cyano-3,12-dioxooleana-1,9 (11)-dien-28-oic acid (CDDO), its methyl ester (CDDO-Me), and imidazolide (CDDO-Im) that mimic natural triterpenoids in physical and chemical properties are effective in inducing apoptosis in a variety of cancer cells and retard tumor growth in vivo [14-16] has rejuvenated interest in this field of research. In this review, we will discuss the enormous potential of various plant-based triterpenoids that have in recent years shown great promise as chemopreventive and therapeutic agents by inhibiting key signaling molecules, inflammatory mediators, tumor cell proliferation, invasion, metastasis, and angiogenesis in various in vitro and in vivo models of cancer. In vivo antitumor activity of terpenoids is summarized in Table 1. A schematic diagram depicting the potential effects of these triterpenoids on pro-inflammatory mediators is shown in Fig. 2.

\section{Asiatic acid}

Asiatic acid (AA) is a pentacyclic triterpenoid derived from the tropical medicinal plant, Centella asiatica (Apiaceae) [17]. Pentacyclic triterpenoids have been found to have wide-ranging pharmacological effects and in particular AA has been shown to reduce inflammation, inhibit tumor cell proliferation, and induce apoptosis through a mitochondria-dependent pathway [18]. Its anti-cancer efficacy is attributed to its ability to inhibit transcription factor $\mathrm{NF}-\kappa \mathrm{B}, \mathrm{p} 38 \mathrm{MAP}$ and ERK kinases in a variety of tumor cells [18-21]. AA induced apoptotic cell death in human hepatoma and malignant glioma cells through enhancing intracellular

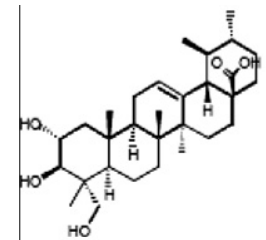

Asiatic acid<smiles>Cc1ccc2c(c1)CCC1C3CCC4CC(C)(C)CCC4(CCC13)CC2=O</smiles>

Celastrol<smiles>C=C(C)C1CCC2(C)CCC3(C)C(CCC4C5(C)CCC(O)C(C)(C)C5CCC43C)C12</smiles>

Lupeol

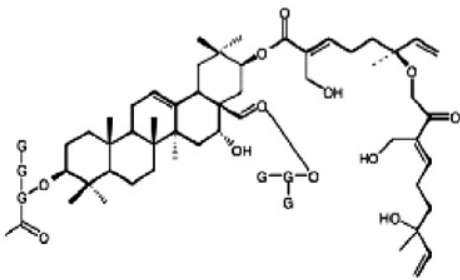

Avicin

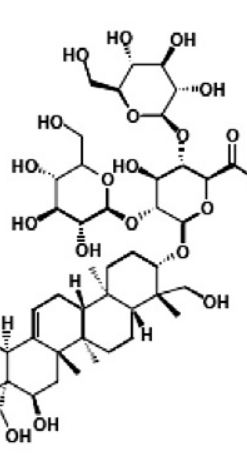

Escin

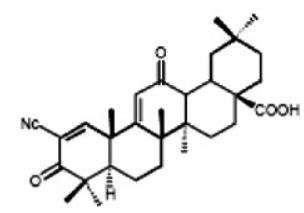

CDDO<smiles></smiles>

Betulinic acid

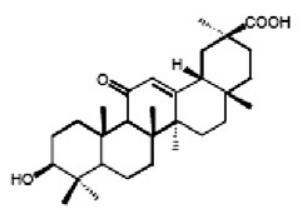

Glycyrrhizin

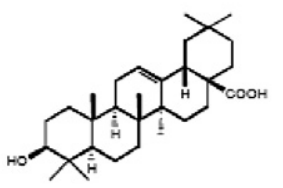

Oleanolic acid

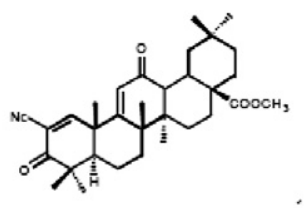

CDDO-Me

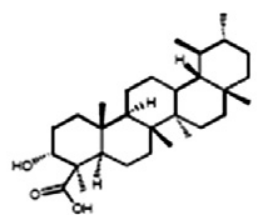

Boswellic acid

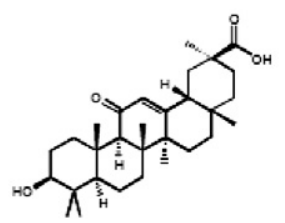

18-ß-Glycyrrhetinic acid

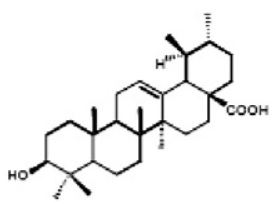

Ursolic acid

Fig. 1. Chemical structures of selected triterpenoids that have been studied extensively in various tumor models. 
Table 1

In vivo effects of natural and semi-synthetic pentacyclic triterpenoids in various animal models of cancer.

\begin{tabular}{|c|c|c|c|}
\hline $\begin{array}{l}\text { Pentacyclic } \\
\text { triterpenoids }\end{array}$ & In vivo cancer models & $\begin{array}{l}\text { Signal transduction } \\
\text { pathways }\end{array}$ & References \\
\hline $\begin{array}{l}\text { Acetyl-11-keto- } \\
\text { beta-boswellic } \\
\text { acid (AKBA) }\end{array}$ & $\begin{array}{l}\text { Suppresses the growth of subcutaneously implanted human glioma; colon tumor; } \\
\text { leukemia; hepatocellular carcinoma; prostate tumor in nude mice. Suppresses the } \\
\text { growth of orthotopically implanted colorectal cancer cells in nude mice. }\end{array}$ & NF- $\kappa$ B; STAT3 & {$[67,68,76]$} \\
\hline Avicin & Suppresses the growth of UVB induced skin cancer in UVB skin cancer model & $\begin{array}{l}\text { NF-KB; STAT3; VEGF; } \\
\text { NRF2-Keap1 }\end{array}$ & {$[33,39]$} \\
\hline Betulinic acid & $\begin{array}{l}\text { Suppresses the growth of subcutaneously implanted human melanoma xenografts in } \\
\text { nude mice; UVB induced photocarcinogenesis in nude mice. }\end{array}$ & NF-кB; ROS & {$[43,61,62]$} \\
\hline \multirow{2}{*}{$\begin{array}{l}\text { Celastrol } \\
\text { CA19 }\end{array}$} & \multirow{2}{*}{$\begin{array}{l}\text { Suppresses the growth of subcutaneously implanted human melanoma tumors and } \\
\text { metastasis in syngenic mice model and the growth of human PC3 prostate tumor; } \\
\text { MDA-MB- } 231 \text { breast tumor; and glioma in nude mice. }\end{array}$} & NF-кB; STAT3; ATF2 & \multirow[t]{2}{*}[87,90,91,96,102-104]{} \\
\hline & & $\begin{array}{l}\text { AKT/mTOR/p70S6K; } \\
\text { DR4/5 }\end{array}$ & \\
\hline Lupeol & $\begin{array}{l}\text { Suppresses the growth of skin cancer in CD1 mice model; Suppresses the growth of } \\
\text { orthotopically implanted head and neck cancer; Suppresses the growth of human } \\
\text { melanoma tumor; pancreatic; hepatocellular carcinoma in nude mice. }\end{array}$ & $\begin{array}{l}\text { NF- } \mathrm{B} ; \text { PI3K/Akt; PTEN/ } \\
\text { Akt/ABCG2 }\end{array}$ & {$[134,135,140,144,146]$} \\
\hline $\begin{array}{l}\text { Oleanolic acid } \\
\text { Amooranin (AMR) }\end{array}$ & $\begin{array}{l}\text { Suppresses the growth of subcutaneously implanted colon cancer in F344 rats and } \\
\text { skin carcinogenesis }\end{array}$ & NF- $\kappa$ B; JAK/STAT3 & {$[147,151,153]$} \\
\hline Synthetic & Suppresses the growth of subcutaneously implanted transgenic pancreatic tumor; and & NF-КB; JAK/STAT3; & {$[11,153,209-$} \\
\hline triterpenoids & orthotopically implanted pancreatic tumor; breast cancer in BRCA1-mutated mice; & AKT; & $212,214,218]$ \\
\hline CDDO-me & HT-29 and MC38 human colon tumor; EL-4 thymoma in nude mice model. Lung cancer & NRF2-Keap1; DR4/5 & \\
\hline AMR-me & $\begin{array}{l}\text { induced by vinyl carbamate in } \mathrm{A} / \mathrm{j} \text { mice model; prostate cancer in TRAMP mice model and } \\
\text { lewis lung carcinoma in SCID-beige mice model }\end{array}$ & & \\
\hline Ursolic acid & $\begin{array}{l}\text { Suppresses the growth of subcutaneously implanted human prostate cancer tumor in } \\
\text { nude mice; and spontaneously developing prostate tumor in TRAMP mice model }\end{array}$ & NF-кB; JAK/STAT3; AKT & {$[185,186]$} \\
\hline
\end{tabular}

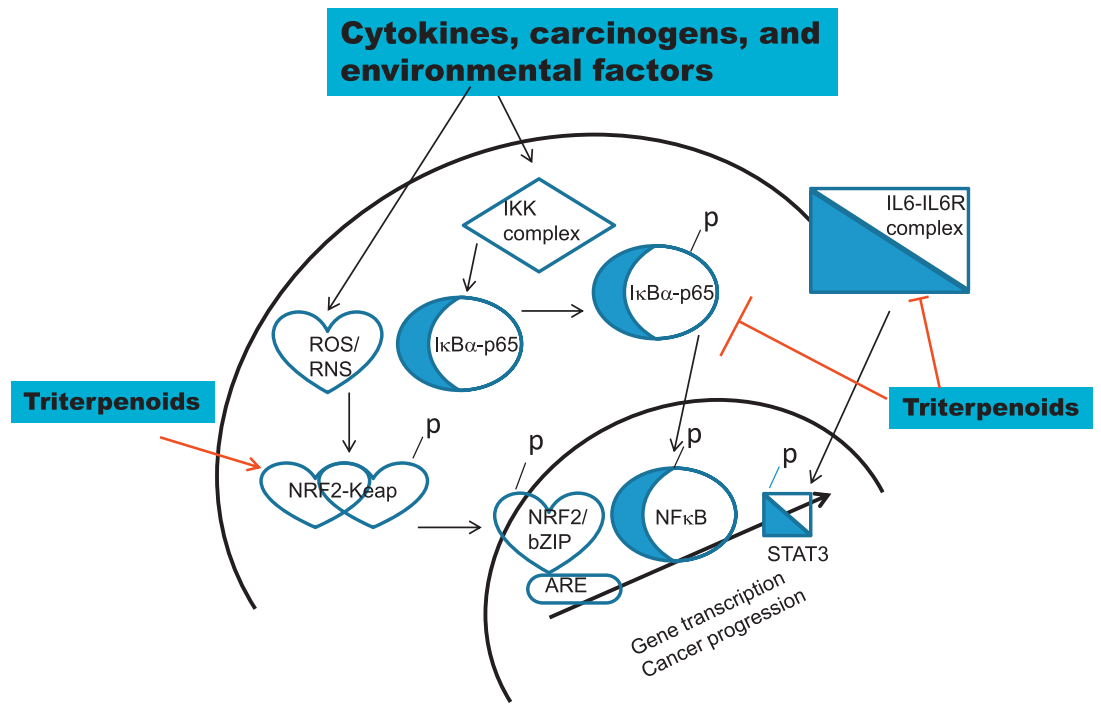

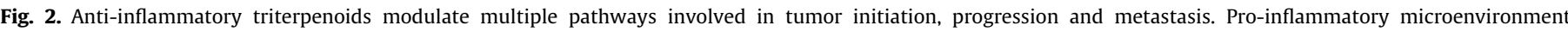

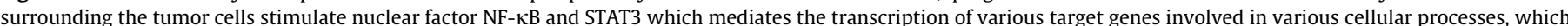

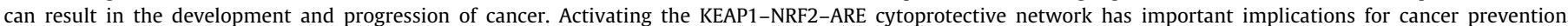

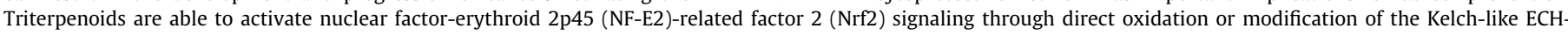

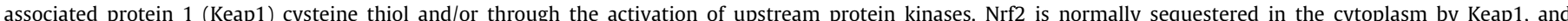

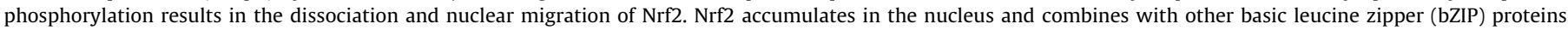

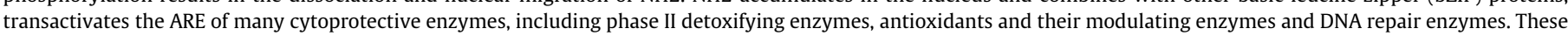

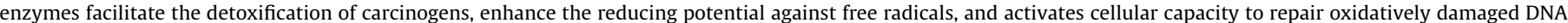
and proteins.

calcium release $[22,23]$. AA as well as $C$. asiatica extract have also been shown to inhibit HT-29 colon cancer cells in vitro and in azoxymethane-induced aberrant crypt formation and colon cancer in the intestines of F344 rats [24,25]. Topical application of AA was shown to reduce mouse ear inflammation induced by TPA or arachidonic acid [26] and skin tumor formation in ICR mice by inhibiting TPA induced generation of NO and expression of iNOS and COX2 [27]. Despite these widely described anti-cancer properties, additional studies are required especially to investigate anti-angiogenic and anti-metastatic potential of AA in vivo.

\section{Avicins}

Avicins comprise a family of plant derived pentacyclic triterpenoids, was first identified in the desert plant, Acacia victoriae (Leguminosae). Using HPLC fractionation procedure, the plant extract was subjected to cytotoxicity assay. Two fractions, namely avicin $\mathrm{D}$ and avicin $\mathrm{G}$ were identified as bioactive [28-30]. Subsequent studies with avicins revealed its dual role as a potent inhibitor of activation of NF- $\kappa \mathrm{B}$ [31] and activate NF-E2-related factor 2 (Nrf2) [32] in a redox-dependent manner, accounting for its 
anti-inflammatory [33] and antioxidant properties, respectively [32] probably by its ability to interact with critical cysteine residues. Interstingly, Haridas et al. showed that avicins interact with and modify cysteine residues in a bacterial system with redox sensitive transcritptional activator, OxyR of Escherichia coli as a target, wherein the distal portion of the avicin side-chain formed a reversible and covalent thioester bond with the critical cysteine $(\mathrm{SH})$ on the OxyR molecule [34] that provide adaptive response to oxidative and nitrosative stress. Avicins also selectively inhibited the growth of various tumor cells, activated the intrinsic caspase pathway to induce apoptosis by direct perturbation of mitochondria, and down-regulated a group of pro-survival, anti-apoptotic proteins, mitochondrial and Fas mediated apoptotic cascades, as well as autophagy associated non-apoptotic programmed cell death $[28,29,31,35-37]$. In a recent report, avicin D was shown to induce not only apoptotic but also autophagic cell death by the depletion of the cell energy supply, suggesting a potential therapeutic application of avicins in apoptosis-resistant cancer [36]. In addition to their cytotoxic properties, avicins possess cytoprotective effects against non-transformed cells, in part related to the activation of the transcription factor, Nrf-2 [32]. Activation of proteins downstream of Nrf2, such as glutathione peroxidase, heme-oxygenase, and thioredoxin reductase, accounts in part for the antioxidant, antimutagenic and tissue protective effects of avicins, both in vitro and in vivo [32,33]. The studies indicated that avicins act as multifunctional compounds, and not only inhibit tumor cell growth but may also play a role in the maintenance of cellular homeostasis. Increasing evidences have shown that avicins may affect multiple cellular processes such as inhibition of growth factor signaling, inflammation, and oxidative stress response, trigger cell death by activation of apoptotic molecules, increase the cellular stress response pathway and, by induction of AMPK-tuberous sclerosis complex 2 (TSC2)-mammalian target of rapapmycin (mTOR) pathway, lead to autophagic cell death [38]. Another recent report indicated that avicin D treatment can cause Fas to translocate to the cholesterol- and sphingolipid-enriched membrane microdomains of lipid rafts where it interacts with Fas-associated death domain (FADD) and caspase-8 to form death-inducing signaling complex (DISC) and thus cell apoptosis. By using cholesteroldepleting methy- $\beta$-cyclodextrin they show that avicin D prevents the association of Fas to DISC complex [37,38]. Avicins dephosphorylate STAT3 and inhibit STAT3 activity in a variety of tumor cell lines. The STAT3-regulated proteins such as c-myc, cyclin D1, Bcl-2, survivin and VEGF were shown to be downregulated while dephosphorylation of JAKs and activation of protein phosphatase 1 contribute to the induction of apoptosis of tumor cells [39,40] and inhibited VEGF in a mouse skin carcinogenesis model via inhibiting STAT3 activation [39]. Jurkat cells showed a decrease in the levels of cellular ATP and the rate of oxygen consumption upon avicin D treatment probably mediated by permeabilized outer mitochondrial membrane, leading to the release of cytochrome-C. The released cytochrome then binds to APAF1 and pro-caspase 9, to form apoptosomes, which can then drive the autocatalytic procession of effector caspases [38,41,42]. Avicins have been shown to reduce $H$-ras mutations and aneuploidy in a mouse model of skin carcinogenesis and decreased p53 mutations in the murine ultraviolet-B skin cancer model [33]. Thus, avicins appears to be a novel and potent molecule that can modulate diverse inflammatory pathways that are mostly activated in human carcinomas.

\section{Betulinic acid}

Betulinic acid (BetA) belongs to the lupane class of pentacyclic triterpenoid that was first isolated from the stem bark of Zizyphus mauritiana in 1995 [43] and has been found in many plants viz.
Tryphyllum peltaum, Ancistrocladus heyneaus, Zizyphus joazeiro, Diospyoros leucomelas, Tetracera boliviana, and Syzygium formosanum [43]. The anticancer activity of BetA has been demonstrated in both in vitro and in vivo tumor models as well as in human clinical trials. Pisha et al. identified BetA as a melanoma specific cytotoxic agent that especially induced apoptosis of melanoma cells in cultures and inhibited the growth of human melanoma tumors implanted subcutaneously in athymic mice without any associated systemic toxicity [43]. Subsequent studies with BetA showed selective cytotoxicity on a variety of tumor cell lines but not on normal cells [44] and induced apoptosis in neuroblastoma and glioblastoma cells through the activation of the mitochondrial pathway $[45,46]$. Interestingly, a report by Tan et al. showed that apoptosis induced by BetA was mediated by activation of MAPK kinase pathway without involvement of activated caspases [47]. Activated NF- $\kappa B$ and STAT3 is frequently observed in tumor cells proliferation, invasion, metastasis and angiogenesis. Takada and Aggarwal, investigated the effect of BetA on constitutive and inducible NF- $\kappa B$ activation pathway induced by a variety of stimulants such as TNF- $\alpha$, PMA, cigarette smoke, okadaic acid, IL-1, and $\mathrm{H}_{2} \mathrm{O}_{2}$ in $\mathrm{H} 1299$ cells (lung adenocarcinoma), HCT 116 and Caco-2 cells (colon carcinoma) [48]. They found that BetA suppressed IkB $\alpha$ kinase activation and subsequent phosphorylation of IkB $\alpha$ and p65 translocation to the nucleus. This correlated with the down-regulation of various proliferative and anti-apoptotic and metastatic gene products including COX-2, cyclin D1, Bcl-2, Bcl-xL and MMPs. Chintharlapalli et al. showed that BetA inhibited prostate cancer growth through inhibition of the transcription factors, specificity protein1 (Sp1), Sp3, and Sp4 which regulate VEGF and survivin expression [49]. Furthemore, BetA has been shown to inhibit constitutive activation of STAT3, Src kinase, JAK1 and JAK2 and induce the expression of the protein tyrosine phosphatase, SHP-1. Silencing of the SHP-1 gene abolished the ability of BetA to inhibit STAT3 activation and also rescued tumor cells from BetA-induced cell death. BetA also significantly downregulated the expression of STAT3 regulated gene products such as, Bcl-xL, Bcl-2, cyclin D1 and survivin [50]. 23-hydroxy betulinic acid, isolated from Pulsatilla chinensis induced apoptosis of HL-60 cells by downregulating Bcl-2 and telomerase activity and of colorectal cancer cells by modulating mitochondrial membrane potential [51]. In a cell-free system, BetA has been demonstrated to directly cause mitochondrial outer membrane permeabilization and cytochrome-c release in a Bcl-2 or Bcl-xL-dependent manner, yet independently of caspases [5254]. BetA has also been reported to induce apoptosis in a p53-independent fashion, including chemotherapy-refractory cases $[44,45,54-58]$ indicating that this tritepene can also overcome chemoresistance, which is frequently encountered during cancer therapy suggesting tremendous potential for development as a therapeutic agent. Recent evidence indicates that the anticancer activity of BetA can be markedly increased when it is used in combination with conventional chemotherapy, ionizing radiation or cytokine TRAIL $[57,59,60]$. Furthermore BetA analogs have displayed significant anti-inflammatory activities in various animal models [61]. Fukuda et al. showed that oral administration of BetA prevented ultravioletB-induced photocarcinogenesis [62]. Similarly, NVX-207, a synthetic derivative of BetA, was shown to have potent anti-cancer activity. NVX-207 at $3.5 \mu \mathrm{M}$ showed anti-tumor activity against various human and canine cell lines, and induced apoptosis by activation of caspase-3. Global gene expression profiling demonstrated that NVX-207 upregulated genes coding for lipid metabolism and cholesterol transport. A phase I/II study in dogs suffering from naturally occurring cancer receiving topical treatment of NVX-207 $(10 \mathrm{mg} / \mathrm{ml})$ showed excellent clinical responses including a complete remission in all animals receiving treatment. NVX-207 is also well tolerated and has significant anti-cancer activity both in vitro and in vivo [63]. 


\section{Boswellic acid}

The gum resin form the plant Boswellia serrate (Synonym: Salai guggul) has been traditionally used for the treatment of inflammation driven diseases such as arthritis, respiratory diseases and liver disorders [64]. The bioactive components of this resin are boswellic acid (BA) and its derivatives acetyl- $\beta$-boswellic acid, 11-keto- $\beta$-boswellic acid, and acetyl-11-keto- $\beta$-boswellic acid (AKBA) [64]. BA was first identified as a potent anti-inflammatory compound that mediated its effect through inhibition of 5-LOX and leukocyte elastase [65]. In animal models of inflammation, BA has been shown to be effective against chronic inflammation-driven diseases such as adjuvant or bovine serum albumininduced arthritis, osteoarthritis, Crohn's disease, ulcerative colitis, and ileitis, and galactosamine/endotoxin-induced hepatitis in mice [64]. Besides its anti-inflammatory effects, BA also exhibits antitumor effects as indicated by its activity against brain tumors cells, leukemic cells, colon cancer cells, metastatic melanoma, fibrosarcoma, and hepatoma cells [2]. BA induced apoptosis was mediated by cell cycle arrest in the G1 phase and by activating caspases 3, 8 and 9 in HT-29 cells [66]. STAT3 activation has been linked with cancer cell survival, proliferation, chemoresistant and angiogenesis. Kunnumakkara et al. demonstrated that BA inhibited the growth of multiple myeloma cells by suppression of STAT3 pathway and by activation of protein tyrosine phosphatase SHP1 [67]. Furthermore, BA down regulated the expression of NF$\kappa \mathrm{B}$, cyclin D1, COX2, Ki-67, CD-31 and IAPs in the tumor tissue. The presence of $\mathrm{BA}$ was detected in blood and in the tumor tissue indicating bioavailability at the tumor site [68]. BA has also been shown to inhibit azoxymethane-induced formation of aberrant crypt foci in the colon of mice [69,70]. Interestingly, AKBA also exhibited similar anti-tumor activity as BA. AKBA induced cell cycle arrest was mediated by down-regulating the expression of cyclinD1, suppresses MMP activity, and also induced apoptosis by suppressing $\mathrm{Bcl}-2$, and $\mathrm{Bcl}-\mathrm{xL}$ expression, [71]. Most of the pro-inflammatory effects of TNF- $\alpha$ are mediated through activation of NF- $\kappa B$. RANKL, another member of the TNF- $\alpha$ superfamily, has been found to mediate osteoclastogenesis through the NF- $\mathrm{BB}$ activation pathway. The results showed that AKBA potentiated apoptosis induced by TNF- $\alpha$ and chemotherapeutic agents, inhibited TNF- $\alpha$-induced cell invasion, and abrogated RANKL-induced osteoclastogenesis through inhibition of NF- $\kappa B$ activation. AKBA inhibited lipopolysaccharide induced production of TNF- $\alpha$ in monocytes was mediated by suppression of I $\mathrm{B} \alpha$ kinases [72]. In vivo treatment with AKBA inhibited the growth and metastasis of colorectal cancer in orthotopically implanted tumors in nude mice. They found that the oral administration of AKBA (50$200 \mathrm{mg} / \mathrm{kg}$ ) dose-dependently inhibited the growth of colorectal tumors with no adverse side effects. Other studies showed that $\mathrm{BA}$ and its novel cyano derivative of 11-keto- $\beta$-boswellic acid inhibited Ehrlich ascites tumor [73,74], novel 11-keto- $\beta$-boswellic acid inhibited promyelocytic leukemia cells, HL-60, in both ascites and solid tumor model, was mediated through the inhibition of topoisomerase I and II [75] and AKBA suppressed human prostate tumor xenografts in nude mice [76]. Shah et al. showed that 24$\mathrm{NH} 2$ substituted $\beta$-boswellic acid derivatives exhibited much more potent apoptosis induction and cell proliferation inhibition than their parent 24- $\mathrm{COOH}$ compounds. Interestingly, the acylation of 24-amino group, or epimerization of $3 \alpha-\mathrm{OH}$ resulted in loss of apoptotic activity [77]. The apoptotic induction of AKBA is independent of Fas and FasL interaction [66], and is p21 dependent but not p53-dependent [78]. In addition, AKBA can enhance the apoptosis induced by TNF- $\alpha$ and some chemotherapeutic agents, as well as inhibit invasion through inhibition of NF- $\mathrm{B}$ activity, and subsequent downregulation of $\mathrm{Bcl}-2$ and $\mathrm{Bcl}-\mathrm{xL}$ in prostate cancer cell line PC-3 [71,79]. Topical application of BA exhibited significant anti-inflammatory and pro-apoptotic activity in animal models of inflammation and is currently being tested in clinical trials [80-82]. These observations support the use of BA and AKBA for both prevention and treatment of inflammation driven cancers.

\section{Celastrol}

Celastrol (tripterine), a quinine methide triterpenoid, is the most abundant bioactive compound derived from the root of Trypterigium wilfordii Hook L also known as 'Thunder of God Vine'. Celastrol has attracted great interest recently, especially for its potential anti-inflammatory and anti-cancer activities. The in vivo anti-inflammatory effects of this triterpene have been demonstrated in animal models of collagen-induced arthritis, rheumatoid arthritis, Alzheimer's disease, asthma, and systemic lupus erythematosus [83-85]. This triterpene has also been found to suppress tumor initiation, promotion and metastasis in various cancer models through modulation of multiple pro-inflammatory cytokines, chemokines, enzymes and transcription factors [4,86-91]. For example, celastrol has been shown to inhibit the proliferation of a wide variety of tumor cells $[6,83,92-94]$. Studies to define its therapeutic mechanism showed that it can suppress the NF- $\kappa B$ signaling pathway [83,95], VEGFR expression [96], inhibit AKT/mTOR pathway [87], suppresses Bcr/Abl and induce apoptosis in imatinib resistant chronic leukemia cells [97], inhibit heat shock protein (HSP) 90 [98,99], ERK [100], proteasomes [93,101] and activate caspase8 [102]. This triterpene has also been shown to directly target Cys-179 in the activation loop of IKK- $\beta$ kinase and also modulate the expression of proteins with cell survival (IAP1, XIAP, Bcl-2, Bcl-xL, cFLIP, survivin), cell proliferation (cyclin D1, COX-2), angiogenic, and metastatic (MMP-9, ICAM-1, VEGF) activities in tumor cells $[83,96]$. We have also recently demonstrated that celastrol can indeed potentiate the apoptotic effects of botezomib and thalidomide by suppression of both NF- $\kappa \mathrm{B}$ and STAT3 activation in multiple myeloma cells [92]. Celastrol up-regulates death receptor 4 (DR4) and 5 (DR5) expression at mRNA, and cell surface receptor levels, and knockdown of DR4 or DR5 attenuates the PARP cleavage caused by the combination of celastrol and TRAIL/Apo-2L, denoting the critical roles of DR induction in this sensitization of cells to apoptosis [91]. Celastrol analogs, pristimerin and dihydrocelastrol, have been shown to induce heat shock response and protect against lethal stress in HeLa cells and SH-SY5Y neuronal cells [98]. In another report, Abbas et al. synthesized a series of celastrol derivatives in which the carboxylic acid group was converted to amide or ester derivatives with the quinone methide functional group intact. They found that the benzyl ester and isopropyl ester derivatives of celastrol was cytotoxic to melanoma cells and induced apoptosis in a dose and time dependent manner [102]. The antitumor effects of celastrol is not limited to in vitro study, it also suppressed the growth and metastasis of melanoma in syngeneic and xenograft mouse models [102], human prostate tumor xenografts [93], celastrol in combination with trastuzumab retarded the rate of growth of ErbB2-overexpressing human breast cancer cells in a mouse xenograft model with minimal systemic toxicity [103] and human glioma xenografts in nude mice [96] Celastrol showed potent antimetastatic activity both in in vitro focal adhesion-dependent cell migration and invasion assay and in vivo using the B16F10-green fluorescent protein-injected C57BL/6 mouse model, as indicated by decreased pulmonary metastases in celastrol-administrated mice [104]. Further studies are needed to better understand the mechanism(s) of action of various celastrol analogs and their therapeutic potential for cancer. 


\section{Escin}

Escin, a pentacyclic triterpenoid, is the major bioactive principle found in the seeds of horse chestnut (Aesculus hippocastanum) [105]. Escin exists in two isomeric forms, $\alpha$ and $\beta$. The $\beta$ form of escin has been described to exhibit anti-inflammatory effects $[105,106]$ and inhibit acute inflammation induced by acetic acid in mice and histamine in rats [107]. ßescin was found to induce apoptosis in human colon cancer HT29 cells by upregulating p21 (Waf1/Cip1) [108]. The primary mechanism of action of $\beta$-escin is via the suppression of the NF- $\kappa \mathrm{B}$ pathway induced by various cytokines and carcinogenic stimuli, leading to the down-regulation of $\mathrm{NF}-\kappa \mathrm{B}-$ linked gene products, potentiation of apoptosis, and inhibition of invasion. Harikumar et al. showed that $\beta$-escin inhibited proliferation and induced apoptosis in KBM-5, K562 (human chronic myeloid leukemia), A293 (human embryonic kidney carcinoma), H1299 (human lung adenocarcinoma), Jurkat (Human Tcell leukemia) and U266 (human multiple myeloma) and HL-60 (human

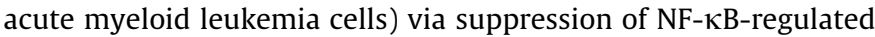
proliferation, apoptotic and metastatic gene products [109-111]. In another recent study, $\beta$-escin inhibited the proliferation and induced apoptosis of cholagiocarcinoma cells. The effect was mediated by activation of the intrinsic mitochondrial and caspase-dependent apoptotic pathway [112]. In a recent study from our lab we have reported the potential of $\beta$-escin to modulate constitutive and inducible STAT3 activation in hepatocellular carcinoma cells. We found that $\beta$-escin downregulated the expression of various STAT3 regulated gene products, such as cyclin D1, Bcl-2, Bcl-xL, survivin, Mcl-1, and VEGF. $\beta$-escin, in combination with paclitaxel or doxorubicin, potentiated the apoptotic effects of the chemotherapeutic compounds, thus its potent suppression of proliferation and chemosensitization of hepatocellular carcinoma $[113,114]$. In combination with 5 -FU, $\beta$-escin showed a synergistic cytotoxic effect in human hepatocellular carcinoma SMMC-7721 by inhibiting induction of apoptosis, cell cycle arrest, activation of caspases-3, 8 and 9, and down-regulation Bcl-2 expression [115]. This triterpene was also found to suppress the expression of adhesion molecules in endothelial cells [116,117]. Recently developed semi-synthetic escin sodium was found to inhibit cell proliferation and induce apoptosis in human lung cancer A549 cell lines by suppressing iNOS expression, JAK/STAT signaling pathway [118]. It induced apoptosis in human acute leukemia Jurkat T cells by activating caspases 3,8 , and 9 with subsequent PARP cleavage. In another study, escin sodium was shown to inhibit endothelial cell migration and motility. The antiangiogenic activity of escin sodium was mediated partly by inhibiting ERK and p38 MAP kinase pathways which are involved in cell proliferation, motility and apoptosis [119]. Futhermore, in vivo $\beta$-escin was shown to produce synergistic anti-inflammatory activity with low dose glucocorticoids [120]. Thus development of novel analogs of $\beta$-escin that suppressest chronic inflammation will be useful in the chemoprevention and therapy of cancer.

\section{Glycyrrhizin and 18ß-glycyrrhetinic acid}

Natural products of herbal origin have received increasing attention in recent years since the discovery of triterpenoids as novel cancer-preventive and therapeutic agents [64]. 18 $\beta$-glycyrrhetinic acid (GA) a pentacyclic triterpenoid from the root of Licorice (Glycyrrhiza glabra) has been extensively used in traditional medicines as natural sweeteners and flavoring agents [121]. GA can inhibit tumor initiation, growth and induction of apoptosis in various cancer cells, including breast cancer cells, promyelocytic leukemia HL-60 cells, human gastric cancer and melanoma cells [122-124]. GA can also suppress the growth of human breast cancer cell line MCF-7 by causing apoptosis via the Akt/FOXO3a/Bim pathway [125]. GA induced apoptotic cell death in SiHa and HepG2 cells by suppressing NF$\kappa \mathrm{B}, \mathrm{H}$-ras, cytochrome-c, $\mathrm{Bcl}-2, \mathrm{Bcl}-\mathrm{xL}$ and activating caspase 3 $[126,127]$. Chintharlapalli et al. reported for the first time that PPAR $\gamma$ agonists derived from glycyrrhetinic acid induced cell-dependent caveolin-1 and KLF-4 expression through receptor-dependent pathways [128]. Furthermore, the effects of glycyrrhizin on the AP-1 activity in untreated and tumor promoter-12-O-tetradecanoylphorbol-13-acetate (TPA)-treated conditions was analyzed. Glycyrrhizin inhibited the TPA-induced AP-1 activation in TPA-treated cells [129]. Glycyrrhizin was shown to suppress estrogen-related endometrial cancer by inhibiting COX-2, IL- $1 \alpha$ and TNF- $\alpha$ [130]. Pretreatment with GA for 2 week conferred protection against UVBradiation induced skin tumor formation in SKH-1 hairless mice [131]. Intraperitoneal administration of GA increased natural killer cell activity in metastatic tumor-bearing animals [132]. It is evident from these studies that the antitumor activity of glycyrrhizin is mediated through the suppression of multiple cell signaling pathways.

\section{Lupeol}

Lupeol, a pentacyclic triterpenoid, occurs abundantly in medicinal herbs and in fruits such as mangoes, olives and fig [133]. This triterpene has been found to suppress proliferation, invasion and metastasis in several cancers. For example, Lupeol was shown to suppress cisplatin induced NF- $\mathrm{KB}$ activation and inhibited the orthotopically implanted head and neck squamous cell carcinoma in nude mice and skin cancer in CD-1 mice [134,135]. Lupeol has been shown to inhibit several pro-inflammatory mediators and oncogenic kinases pathways such as PI3K/AKT dependent pathway [136], and pro-inflammatory molecules such as prostaglandin E2/ TNF- $\alpha /$ IL-1 $\beta$ [137]. In addition, the beneficial and pre-clinical studies using lupeol has been recently reviewed [138]. Interestingly, lupeol was shown to significantly suppress androgen analog R1881induced transcriptional activity of AR and expression of PSA. Lupeol blocked the binding of AR to AR-responsive genes, including PSA, TIPARP, SGK, and IL-6, and inhibited the recruitment of RNA Pol II to target genes [139] and also significantly decreased the transcriptional activation of survivin and cFLIP genes and $\beta$-catenin signaling in prostate and metastatic melanoma cells [140-142]. Lupeol treatment in melanoma cells resulted in a dose-dependent decrease in cell viability, induction of apoptosis, suppressed colonogenic potential, and reduced $\beta$-catenin transcriptional activity and the expression of Wnt target genes [143]. Most importantly, lupeol restricted the translocation of $\beta$-catenin from the cytoplasm to the nucleus and also decreased the growth of melanoma tumors implanted in athymic nude mice. The decrease in melanoma-derived tumor growth was associated with a decrease in the expression of Wnt target genes, such as $c-M y c$, cyclin D1, proliferation marker Ki-67 and invasion marker, osteopontin [143]. Overexpression of cFLIP is reported to confer chemoresistance in pancreatic cancer cells. Lupeol also suppressed expression of cFLIP protein, abolished TRAIL-mediated resistance to apoptosis in chemoresistant pancreatic cancer and inhibited the growth of tumor in nude mice [144]. Furthermore, lupeol exhibited chemopreventive potential in various cancer models [145]. Lupeol sensitized HCC cells to chemotherapeutic agents through the PTEN/Akt/ ABCG2 pathway and inhibited HCC tumor growth in nude mice by down regulating CD133 in tumor tissue [146]. Overall, literature review suggests that lupeol is a potentially efficacious dietary phytochemical that could be used in the prevention and treatment of inflammation driven cancers.

\section{Oleanolic acid}

Oleanolic acid (OA) is an oleanane-type triterpenoid that is widely found in dietary and medicinal plants. OA has been shown 
to act on various stages of tumor development, inhibits tumor initiation and progression in the two-stage mouse skin carcinogenesis model, and conferred protection against $12-0$-tetradecanoyl phorbol-13-acetate induced carcinogenesis [147]. OA is potent inducer of apoptosis in tumor cells. OA was shown to induce apoptosis of HL-60 leukemia cells by activation of caspase- 3 and PARP cleavage [148]. Like OA, Achyranthoside H methyl ester, a novel oleanolic acid saponin derivative from Achyranthes fauriei roots, induced apoptosis in human breast cancer MCF-7 and MDA-MB-453 cells by activating caspase- 3 [149]. In HT-29 cells, the $2-\alpha-O H$ derivative of $\mathrm{OA}$, maslinic acid, induced apoptosis and suppressed COX-2 expression at very low concentrations compared to OA [150,151]. Epi-oleanolic acid, isolated from Korean mistletoe was shown to induce apoptosis in a variety of tumor cells [152]. Amooranin, an oleanane pentacyclic triterpenoid isolated from the stem bark of Amoora rohituka has been shown to inhibit proliferation and induced apoptosis of MCF-7 and MDA-MB-468 cells via caspase activation pathway compared to normal breast epithelial cells MCF10A. Additional studies using a synthetic derivative amooranin methyl ester showed potent activity against breast cancer cells at nanomolar range and inhibited Ehrlich ascites tumor in swiss mice [153]. Synthetic OA derivatives modulated multiple signaling pathways and intracellular signaling molecules including NF- $\mathrm{KB}, \mathrm{AKT}$, STAT3, mTOR, caspases-3, -8 , and -9, ICAM-1, VEGF, and PARP in a variety of cancer cells $[14,154-156]$. In particular, synthetic OA derivatives induced apoptosis of acute myelogenous leukemia cells, upregulated c-Jun $\mathrm{NH} 2$ kinase mediated upregulation of DR5 in lung cancer cells and inhibited angiogenesis, invasion and metastasis of tumor cells [157-159]. The induction of phase-2 enzymes, such as hemeoxygenase 1 and NADPH-quinone oxidoreductase occurs by modulating Nrf2-Keap1 signaling pathway [160]. Cytoprotective enzymes, such as GST and SOD which contain the antioxidant response element (ARE), are Nrf2 and upregulate genes in response to oxidative stress [161]. Importantly, synthetic derivative of oleanolic acid 2-cyano-3,12-dioxoolean-1,9-dien-28oic acid (CDDO), and its C-28 methyl ester (CDDO-Me) and C28 imidazole (CDDO-Im) demonstrated potent anti-inflammatory and antitumor activity [162,163]. Shishodia et al. showed that the inhibitory effect of CDDO-Me was more potent than that of CDDO or CDDO-Im. CDDO-Me inhibited NF- $\kappa$ B signaling activated by a variety of stimulating agents in human leukemia cells. CDDOMe was shown to inhibit IKK $\alpha$ kinase and subsequently I $\mathrm{B} \alpha$ protein phosphorylation and degradation, as well as NF- $\kappa B$-dependent transactivation of the reporter gene [163]. Furthermore, both CDDO-Me and CDDO-Im could inhibit IKK $\beta$ kinase by directly binding to Cys-179 and inhibiting the enzymatic activity of IKK $\beta$ [164-166]. Sohn et al. provided first evidence that OA have antiangiogenic effects on bovine aortic endothelial cells and in chick embryo chorioallantoic membrane assay [167]. Both the synthetic compounds were shown to be potent inhibitors of angiogenesis in Matrigel sponge assay and in immortalized Kaposi's sarcoma cell line. The compounds prevented endothelial cell tubulogenesis when cultured on Matrigel and inhibited vascular endothelial growth factor-induced ERK1/2 pathway in human umbilical vein endothelial cell $[167,168]$. All these results underscore the potential of $\mathrm{OA}$ and its synthetic derivatives both as preventive and therapeutic agents for chronic inflammation driven cancers.

\section{Ursolic acid (UA)}

Ursolic acid (3ß-hydroxy-urs-12-en-28-oic-acid) is a pentacyclic triterpenoid (a member of the cyclosqualenoid family) derived from berries, leaves, flowers, and fruits of medicinal plants, such as Rosemarinus officinalis, Eriobotrya japonica, Calluna vulgaris, Ocimum sanctum, and Eugenia jumbolana, that has been extensively studied for its anti-inflammatory and anti-cancer activities [169]. UA has been reported to suppress the proliferation of a variety of tumor cells, induce apoptosis, and inhibit tumor promotion, metastasis, and angiogenesis in animal models of cancer. He and Liu first isolated and identified 20 pure compounds from cranberries, including UA and showed that these compounds have potent anti-proliferative activities against HepG2, liver cancer cells and MCF7, breast cancer cells [170]. In vitro, UA has been shown to induce apoptosis in a variety of tumor cells, including HL-60, human leukemia cancer cells [171,172], K562 [173], HEC108 and SCG-II, human endometrial cancer cells [174,175], M4Beu human melanoma cells [176], A549, human non-small cell lung cancer cells [177], PC-3 and LNCaP, human prostate cancer cells [178], HaCaT, human keratinocyte cells [179], human Burkitt's lymphoma Daudi cells [180] in a dose- and time-dependent manner. The major mechanisms by which UA induces apoptosis is through inhibition of DNA replication [171], caspases activation [181,182] inactivation of protein tyrosine kinases [183], and induction of $\mathrm{Ca}^{2+}$ release [172,180]. UA also induced apoptosis via NF- $\kappa B$ mediated down-regulation of the cellular inhibitor of apoptosis gene [181]. Furthermore, Shishodia et al. found that UA suppressed NF- $\kappa B$ activation induced by various carcinogens, including TNF$\alpha$, phorbol ester, okadaic acid, $\mathrm{H}_{2} \mathrm{O}_{2}$ and cigarette smoke [184]. This inhibition was mediated through, IKK kinase activation, I $\mathrm{KB} \alpha$ phosphorylation and degradation, p65 phosphorylation, p65 nuclear translocation, and NF- $\kappa B$ dependent reporter gene expression. UA also inhibited NF- $\kappa B$-dependent reporter gene expression activated by TNF- $\alpha$ receptor, TRADD, TRAF2, NIK, IKK, and p65. The inhibition of NF- $\kappa B$ activation correlated with the suppression of NF- $\kappa$ B-dependent cyclin D1, COX-2 and MMP-9 expression [184]. In a recent study by our group we have shown that PTEN knockdown sensitizes androgen independent DU145 cells to UA in a time dependent manner and induced apoptosis in both androgen independent DU145 (overexpress PTEN) and androgen dependent LNCaP cells (PTEN null) [185] and inhibited the growth of DU145 prostate tumor in nude mice. In another study, we reported that UA can inhibit distant site metastasis by inhibiting CXCR4/CXCL12 signaling pathway in TRAMP mice model [186]. UA inhibited both constitutive and IL-6-inducible STAT3 activation [187], and this suppression was mediated through the inhibition of activation of upstream kinases c-Src, JAK1, JAK2 and ERK1/2. It was observed that UA can induce the expression of SHP-1 protein, while knockdown of SHP-1 by siRNA suppressed the induction of SHP-1 and reversed the inhibition of STAT3 activation, thereby indicating the critical role of SHP-1 in the mechanism of action of UA. Thus, UA can be effective in suppressing the inflammatory network consisting of NF- $\mathrm{KB}$, STAT3, and AKT [187]. UA also inhibited COX-2 in PMA-treated human mammary and oral epithelial cells [188]. Honda et al. showed a concise structure activity relationship of UA showing potent nitric oxide inhibitory activity [189]. Recently, novel UA derivatives with promising antiviral activity against human papilloma virus type 11 (HPV) and influenza virus type A (H1N1) have shown growth inhibitory effect of HPV-negative cell lines, C33A, and the HPV-positive cell lines, SiHA (HPV-16), CaSki (HPV-16) and HeLa (HPV-18) [190]. Thus, UA is a novel blocker of inflammation-driven chronic diseases and is one of the most promising triterpenoid-based drug candidates that necessitate further evaluation in clinical trials.

\section{Synthetic triterpenoids}

Novel synthetic triterpenoids which mimic natural triterpenoids in physical and chemical properties have been found to be effective in suppressing inflammation and inducing apoptosis in a wide variety of tumor cells via diverse mechanisms [16,164]. This was first established by the exceptional ability of synthetic oleanane triterpenoids to inhibit inducible NOS induced by TNF- $\alpha$, IL-1 


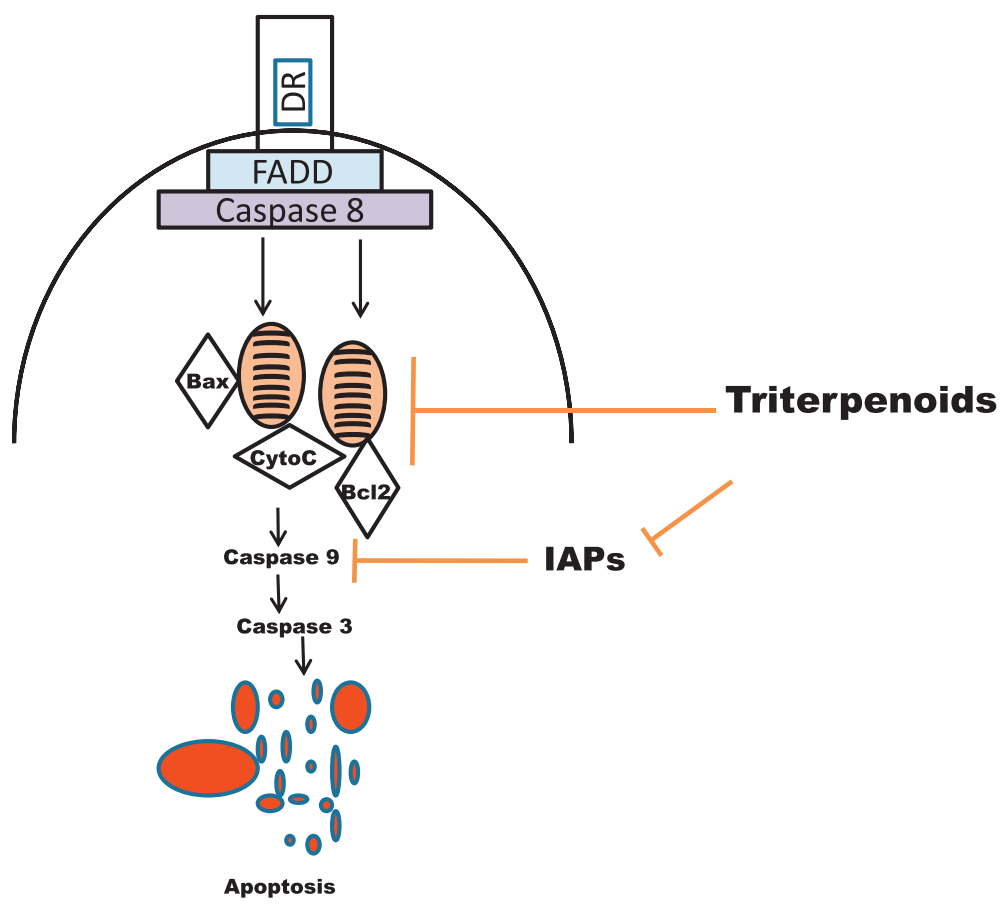

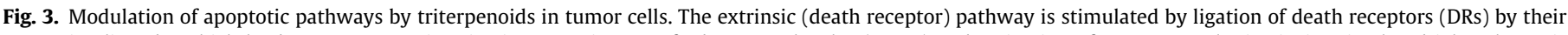

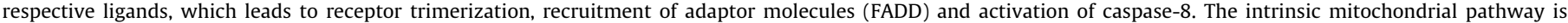

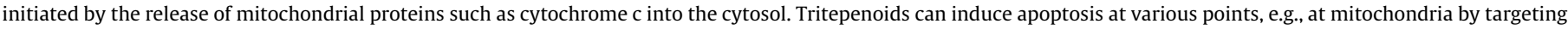
the permeability transition pore complex, by suppression of IAP proteins or by inhibition of anti-apoptotic Bcl-2 proteins.

and IFN- $\gamma$ [191]. These compounds also sensitize tumor cells that do not respond to conventional chemotherapy [192]. Proteomic analysis has led to the identification of important protein targets of synthetic triterpenoids. In many instances, it has been observed that these compounds bind to the active cysteine residue in the proteins [16]. The key proteins that have been reported to be modulated by oleanane triterpenoids are Keap 1 [193, 194], IKK, IkB $\alpha$ and NF- $\mathrm{B}$ [164,166], JAK1 and STAT3 [165,195,196], PTEN [197], AKT [14,198,199], mTOR [200], ROS [201], DR5 and CHOP [202], GSK3 $\beta$ [203], cFLIP and VEGF [204,205], mitochondrial membrane potential [206], and cell cycle arrest $[198,207,208]$. In another study where transgenic LSL-Kras(G12D/+); LSL-Trp53(R127H/+); Pdx-1-Cre (KPC) mouse model of pancreatic cancer were fed with diet containing CDDO-Me or CDDO-ethyl amide, the rexinoid LG100268 significantly increased the survival of mice by 34 weeks [209] and prevented lung cancer development when fed with these terpenoids for 8 weeks [15]. CDDO and CDDO-Me fed for 20 week inhibited the progression of the preneoplastic lesions (low-grade PIN and high-grade-PIN) to adenocarcinoma in the dorsolateral prostate (DLP) and ventral prostate (VP) lobes of TRAMP mice [210,211] prevented breast cancer development in BRCA1mutated mice [212]; pretreatment with oral CDDO-Me improved survival following lethal-dose LPS challenge in mice by modulating the in vivo immune response to LPS [213]; CDDO-Me inhibited orthotopic pancreatic human L3.6pL tumor growth and down-regulated Sp1, Sp3, and Sp4 in tumors [214]. However, these synthetic terpenoids had very poor oral absorption and low bioavailability. To improve its pharmacokinetic profile, a novel CDDO anhydride was synthesized with the same potency as CDDO-Me, but with greater bioavailability [214]. Angiogenesis, particularly 'inflammatory angiogenesis', is a common target of many chemopreventive molecules, which most likely suppress angiogenesis in pre-malignant tumors. CDDO-Im induced DNA-damage, cell cycle arrest and apoptosis in BRCA-1 mutated breast cancer cells [215]; stimulated megakaryocytic differentiation [216]; and inhibited Waldenstrom Macroglobulinemia [217]. CDDO-Im treatment significantly decreased liver metastasis burden in both human colon cancer and B16F1 mice models [218]. CDDO-Me can also inhibit the growth and induce apoptosis of colorectal cancer cells and ovarian cancer cells by suppressing pro-survival signals and NF- $\kappa B$ signaling proteins [219]. Both CDDO-Me and CDDO-Im has been shown to inhibit tumor angiogenesis in vivo and are currently in phase 1 clinical trials in the US [168]. Other novel synthetic derivatives, such as cyanoenones of boswellic acid and glycyrrhetinic acid, showed potent anti-inflammatory and cytotoxic activities [220]. In vitro screening of BA and UA synthetic derivatives have been shown to have antiviral activity against human papillomavirus type 11 and influenza virus type A (H1N1) [221]. It is worth mentioning that the same synthetic route was recently used by Wang et al. to prepare a non-natural derivative of UA bearing this particular trisaccharide residue [222]. A schematic diagram on potential effects of triterpenoids on apoptotic machinery in tumor cells is shown in Fig. 3. However, additional studies are needed to elucidate the full potential of these synthetic derivatives for both the prevention and treatment of cancer.

\section{Conclusion}

Numerous triterpenoids that occur in nature are structurally diverse and in particular pentacyclic triterpenoids have been shown to inhibit cell proliferation, survival, metastasis, angiogenesis and induce apoptosis or enhance the apoptosis induced by other anti-tumor agents/targeted therapies. The diverse bioactivity of structurally related triterpenoids may be well explained by their potential ability to target multiple oncogenic signaling cascades in a wide variety of tumor models. Considering the complexity that drives initiation and progression of cancer, simultaneous targeting of multiple cancer-related proteins by these triterpenoids may pave the way for anticancer drug development. Also, several of the synthetic triterpenoid derivatives, such as CDDO-Me and CDDO-Im, are already in clinical trials that will provide more insights into their potency and efficacy in human 
subjects. Briefly, this review has highlighted the importance of both natural and synthetic triterpenoids, which have the potential for use in both chemoprevention and therapy of various cancers with several common molecular targets. The evidence for the ability of triterpenoids to suppress various key steps of tumor initiation, progression and promotion clearly vindicates their traditional use over the past hundreds of years in the treatment of inflammatory diseases/cancers. These remain to be further validated once the results of ongoing clinical studies are available.

\section{Acknowledgements}

This work was supported by Grants from National Medical Research Council of Singapore [Grant R-184-000-201-275 and R-184-000-211-213], Academic Research Fund [Grant R-184-000207-112] and National Kidney Foundation [Grant R-184-000196-592] to GS. APK was supported by Grants from the National Medical Research Council of Singapore [Grant R-713-000-124213] and Cancer Science Institute of Singapore, Experimental Therapeutics I Program [Grant R-713-001-011-271].

\section{References}

[1] M.J. Balunas, A.D. Kinghorn, Drug discovery from medicinal plants, Life Sci. 78 (2005) 431-441.

[2] B.B. Aggarwal, S. Shishodia, Molecular targets of dietary agents for prevention and therapy of cancer, Biochem. Pharmacol. 71 (2006) 1397-1421.

[3] B.B. Aggarwal, R.V. Vijayalekshmi, B. Sung, Targeting inflammatory pathways for prevention and therapy of cancer: short-term friend, long-term foe, Clin. Cancer Res.: Off. J. Am. Assoc. Cancer Res. 15 (2009) 425-430.

[4] G. Sethi, V. Tergaonkar, Potential pharmacological control of the NF-kappaB pathway, Trends Pharmacol. Sci. 30 (2009) 313-321.

[5] S.I. Grivennikov, M. Karin, Inflammatory cytokines in cancer: tumour necrosis factor and interleukin 6 take the stage, Ann. Rheum. Dis. 70 (Suppl. 1) (2011) i104-i108.

[6] R. Kannaiyan, M.K. Shanmugam, G. Sethi, Molecular targets of celastrol derived from Thunder of God Vine: potential role in the treatment of inflammatory disorders and cancer, Cancer Lett. 303 (2011) 9-20.

[7] B.B. Aggarwal, A.B. Kunnumakkara, K.B. Harikumar, S.T. Tharakan, B. Sung, P. Anand, Potential of spice-derived phytochemicals for cancer prevention, Planta Med. 74 (2008) 1560-1569.

[8] R. Gautam, S.M. Jachak, Recent developments in anti-inflammatory natural products, Med. Res. Rev. 29 (2009) 767-820.

[9] M.K. Shanmugam, R. Kannaiyan, G. Sethi, Targeting cell signaling and apoptotic pathways by dietary agents: role in the prevention and treatment of cancer, Nutr. Cancer 63 (2011) 161-173.

[10] J.D. Connolly, R.A. Hill, Triterpenoids, Nat. Prod. Rep. 27 (2010) 79-132.

[11] K.T. Liby, M.M. Yore, M.B. Sporn, Triterpenoids and rexinoids as multifunctional agents for the prevention and treatment of cancer, Nat Rev. Cancer 7 (2007) 357-369.

[12] A.C. Estrada, T. Syrovets, K. Pitterle, O. Lunov, B. Buchele, J. Schimana-Pfeifer, T. Schmidt, S.A. Morad, T. Simmet, Tirucallic acids are novel pleckstrin homology domain-dependent Akt inhibitors inducing apoptosis in prostate cancer cells, Mol. Pharmacol. 77 (2010) 378-387.

[13] A. Petronelli, G. Pannitteri, U. Testa, Triterpenoids as new promising anticancer drugs, Anticancer Drugs 20 (2009) 880-892.

[14] D. Deeb, X. Gao, S.A. Dulchavsky, S.C. Gautam, CDDO-Me inhibits proliferation, induces apoptosis, down-regulates Akt, mTOR, NF-kappaB and NF-kappaB-regulated antiapoptotic and proangiogenic proteins in TRAMP prostate cancer cells, J. Exp. Ther. Oncol. 7 (2008) 31-39.

[15] K. Liby, D.B. Royce, C.R. Williams, R. Risingsong, M.M. Yore, T. Honda, G.W. Gribble, E. Dmitrovsky, T.A. Sporn, M.B. Sporn, The synthetic triterpenoids CDDO-methyl ester and CDDO-ethyl amide prevent lung cancer induced by vinyl carbamate in A/J mice, Cancer Res. 67 (2007) 2414-2419.

[16] M.B. Sporn, K.T. Liby, M.M. Yore, L. Fu, J.M. Lopchuk, G.W. Gribble, New synthetic triterpenoids: potent agents for prevention and treatment of tissue injury caused by inflammatory and oxidative stress, J. Nat. Prod. 74 (2011) 537-545.

[17] J.T. James, I.A. Dubery, Pentacyclic triterpenoids from the medicinal herb, Centella asiatica (L.) Urban, Molecules 14 (2009) 3922-3941.

[18] X.L. Tang, X.Y. Yang, H.J. Jung, S.Y. Kim, S.Y. Jung, D.Y. Choi, W.C. Park, H. Park, Asiatic acid induces colon cancer cell growth inhibition and apoptosis through mitochondrial death cascade, Biol. Pharm. Bull. 32 (2009) 13991405.

[19] Y.L. Hsu, P.L. Kuo, L.T. Lin, C.C. Lin, Asiatic acid, a triterpene, induces apoptosis and cell cycle arrest through activation of extracellular signal-regulated kinase and p38 mitogen-activated protein kinase pathways in human breast cancer cells, J. Pharmacol. Exp. Ther. 313 (2005) 333-344.
[20] D.M. Gurfinkel, S. Chow, R. Hurren, M. Gronda, C. Henderson, C. Berube, D.W. Hedley, A.D. Schimmer, Disruption of the endoplasmic reticulum and increases in cytoplasmic calcium are early events in cell death induced by the natural triterpenoid Asiatic acid, Apoptosis 11 (2006) 1463-1471.

[21] B.C. Park, K.O. Bosire, E.S. Lee, Y.S. Lee, J.A. Kim, Asiatic acid induces apoptosis in SK-MEL-2 human melanoma cells, Cancer Lett. 218 (2005) 81-90.

[22] Y.S. Lee, D.Q. Jin, E.J. Kwon, S.H. Park, E.S. Lee, T.C. Jeong, D.H. Nam, K. Huh, J.A $\mathrm{Kim}$, Asiatic acid, a triterpene, induces apoptosis through intracellular $\mathrm{Ca}^{2+}$ release and enhanced expression of p53 in HepG2 human hepatoma cells, Cancer Lett. 186 (2002) 83-91.

[23] C.W. Cho, D.S. Choi, M.H. Cardone, C.W. Kim, A.J. Sinskey, C. Rha, Glioblastoma cell death induced by Asiatic acid, Cell Biol. Toxicol. 22 (2006) 393-408.

[24] P. Bunpo, K. Kataoka, H. Arimochi, H. Nakayama, T. Kuwahara, Y. Bando, K. Izumi, U. Vinitketkumnuen, Y. Ohnishi, Inhibitory effects of Centella asiatica on azoxymethane-induced aberrant crypt focus formation and carcinogenesis in the intestines of F344 rats, Food Chem. Toxicol. 42 (2004) 1987-1997.

[25] P. Bunpo, K. Kataoka, H. Arimochi, H. Nakayama, T. Kuwahara, U. Vinitketkumnuen, Y. Ohnishi, Inhibitory effects of Asiatic acid and CPT-11 on growth of HT-29 cells, J. Med. Invest. 52 (2005) 65-73.

[26] M.C. Aguirre, C. Delporte, N. Backhouse, S. Erazo, M.E. Letelier, B.K. Cassels, X Silva, S. Alegria, R. Negrete, Topical anti-inflammatory activity of 2alphahydroxy pentacyclic triterpene acids from the leaves of Ugni molinae, Bioorg. Med. Chem. 14 (2006) 5673-5677.

[27] B.C. Park, S.H. Paek, Y.S. Lee, S.J. Kim, E.S. Lee, H.G. Choi, C.S. Yong, J.A. Kim, Inhibitory effects of asiatic acid on 7,12-dimethylbenz[a]anthracene and 12 O-tetradecanoylphorbol 13-acetate-induced tumor promotion in mice, Biol. Pharm. Bull. 30 (2007) 176-179.

[28] V. Haridas, M. Higuchi, G.S. Jayatilake, D. Bailey, K. Mujoo, M.E. Blake, C.J Arntzen, J.U. Gutterman, Avicins: triterpenoid saponins from Acacia victoriae (Bentham) induce apoptosis by mitochondrial perturbation, Proc. Natl. Acad. Sci. USA 98 (2001) 5821-5826.

[29] K. Mujoo, V. Haridas, J.J. Hoffmann, G.A. Wachter, L.K. Hutter, Y. Lu, M.E. Blake, G.S. Jayatilake, D. Bailey, G.B. Mills, J.U. Gutterman, Triterpenoid saponins from Acacia victoriae (Bentham) decrease tumor cell proliferation and induce apoptosis, Cancer Res. 61 (2001) 5486-5490.

[30] G.S. Jayatilake, D.R. Freeberg, Z. Liu, S.L. Richheimer, M.E. Blake Nieto, D.T. Bailey, V. Haridas, J.U. Gutterman, Isolation and structures of avicins D and G: in vitro tumor-inhibitory saponins derived from Acacia victoriae, J. Nat. Prod. 66 (2003) 779-783.

[31] V. Haridas, C.J. Arntzen, J.U. Gutterman, Avicins, a family of triterpenoid saponins from Acacia victoriae (Bentham), inhibit activation of nuclear factorkappaB by inhibiting both its nuclear localization and ability to bind DNA, Proc. Natl. Acad. Sci. USA 98 (2001) 11557-11562.

[32] V. Haridas, M. Hanausek, G. Nishimura, H. Soehnge, A. Gaikwad, M. Narog, E. Spears, R. Zoltaszek, Z. Walaszek, J.U. Gutterman, Triterpenoid electrophiles (avicins) activate the innate stress response by redox regulation of a gene battery, J. Clin. Invest. 113 (2004) 65-73.

[33] M. Hanausek, P. Ganesh, Z. Walaszek, C.J. Arntzen, T.J. Slaga, J.U. Gutterman, Avicins, a family of triterpenoid saponins from Acacia victoriae (Bentham), suppress $\mathrm{H}$-ras mutations and aneuploidy in a murine skin carcinogenesis model, Proc. Natl. Acad. Sci. USA 98 (2001) 11551-11556.

[34] V. Haridas, S.O. Kim, G. Nishimura, A. Hausladen, J.S. Stamler, J.U. Gutterman, Avicinylation (thioesterification): a protein modification that can regulate the response to oxidative and nitrosative stress, Proc. Natl. Acad. Sci. USA 102 (2005) 10088-10093.

[35] A. Gaikwad, A. Poblenz, V. Haridas, C. Zhang, M. Duvic, J. Gutterman, Triterpenoid electrophiles (avicins) suppress heat shock protein-70 and $\mathrm{x}$ linked inhibitor of apoptosis proteins in malignant cells by activation of ubiquitin machinery: implications for proapoptotic activity, Clin. Cancer Res. 11 (2005) 1953-1962.

[36] Z.X. Xu, J. Liang, V. Haridas, A. Gaikwad, F.P. Connolly, G.B. Mills, J.U. Gutterman, A plant triterpenoid, avicin D, induces autophagy by activation of AMP-activated protein kinase, Cell Death Differ. 14 (2007) 1948-1957.

[37] Z.X. Xu, T. Ding, V. Haridas, F. Connolly, J.U. Gutterman, Avicin D, a plant triterpenoid, induces cell apoptosis by recruitment of Fas and downstream signaling molecules into lipid rafts, PLoS ONE 4 (2009) e8532.

[38] H. Wang, V. Haridas, J.U. Gutterman, Z.X. Xu, Natural triterpenoid avicins selectively induce tumor cell death, Commun. Integr. Biol. 3 (2010) 205-208.

[39] V. Haridas, G. Nishimura, Z.X. Xu, F. Connolly, M. Hanausek, Z. Walaszek, R. Zoltaszek, J.U. Gutterman, Avicin D: a protein reactive plant isoprenoid dephosphorylates Stat 3 by regulating both kinase and phosphatase activities, PLOS ONE 4 (2009) e5578.

[40] C. Zhang, B. Li, A.S. Gaikwad, V. Haridas, Z. Xu, J.U. Gutterman, M. Duvic Avicin D selectively induces apoptosis and downregulates p-STAT-3, bcl-2, and survivin in cutaneous T-cell lymphoma cells, J. Invest. Dermatol. 128 (2008) 2728-2735.

[41] V. Haridas, X. Li, T. Mizumachi, M. Higuchi, V.V. Lemeshko, M. Colombini, J.U. Gutterman, Avicins, a novel plant-derived metabolite lowers energy metabolism in tumor cells by targeting the outer mitochondrial membrane, Mitochondrion 7 (2007) 234-240.

[42] V.V. Lemeshko, V. Haridas, J.C. Quijano Perez, J.U. Gutterman, Avicins, natura anticancer saponins, permeabilize mitochondrial membranes, Arch. Biochem. Biophys. 454 (2006) 114-122.

[43] E. Pisha, H. Chai, I.S. Lee, T.E. Chagwedera, N.R. Farnsworth, G.A. Cordell, C.W Beecher, H.H. Fong, A.D. Kinghorn, D.M. Brown, et al., Discovery of betulinic 
acid as a selective inhibitor of human melanoma that functions by induction of apoptosis, Nat. Med. 1 (1995) 1046-1051.

[44] V. Zuco, R. Supino, S.C. Righetti, L. Cleris, E. Marchesi, C. Gambacorti-Passerini, F. Formelli, Selective cytotoxicity of betulinic acid on tumor cell lines, but not on normal cells, Cancer Lett. 175 (2002) 17-25.

[45] S. Fulda, C. Friesen, M. Los, C. Scaffidi, W. Mier, M. Benedict, G. Nunez, P.H Krammer, M.E. Peter, K.M. Debatin, Betulinic acid triggers CD95 (APO-1/Fas)and p53-independent apoptosis via activation of caspases in neuroectodermal tumors, Cancer Res. 57 (1997) 4956-4964.

[46] I. Jeremias, H.H. Steiner, A. Benner, K.M. Debatin, C. Herold-Mende, Cell death induction by betulinic acid, ceramide and TRAIL in primary glioblastoma multiforme cells, Acta Neurochir. (Wien) 146 (2004) 721-729.

[47] Y. Tan, R. Yu, J.M. Pezzuto, Betulinic acid-induced programmed cell death in human melanoma cells involves mitogen-activated protein kinase activation Clin. Cancer Res. 9 (2003) 2866-2875.

[48] Y. Takada, B.B. Aggarwal, Betulinic acid suppresses carcinogen-induced NFkappa B activation through inhibition of I kappa B alpha kinase and p65 phosphorylation: abrogation of cyclooxygenase-2 and matrix metalloprotease-9, J. Immunol. 171 (2003) 3278-3286.

[49] S. Chintharlapalli, S. Papineni, S.K. Ramaiah, S. Safe, Betulinic acid inhibits prostate cancer growth through inhibition of specificity protein transcription factors, Cancer Res. 67 (2007) 2816-2823.

[50] M.K. Pandey, B. Sung, B.B. Aggarwal, Betulinic acid suppresses STAT3 activation pathway through induction of protein tyrosine phosphatase SHP1 in human multiple myeloma cells, Int. J. Cancer. J. Int. du Cancer 127 (2010) $282-292$.

[51] Z.N. Ji, W.C. Ye, G.G. Liu, W.L. Hsiao, 23-Hydroxybetulinic acid-mediated apoptosis is accompanied by decreases in bcl-2 expression and telomerase activity in HL-60 Cells, Life Sci. 72 (2002) 1-9.

[52] S. Fulda, C. Scaffidi, S.A. Susin, P.H. Krammer, G. Kroemer, M.E. Peter, K.M. Debatin, Activation of mitochondria and release of mitochondrial apoptogenic factors by betulinic acid, J. Biol. Chem. 273 (1998) 33942-33948.

[53] S. Fulda, G. Kroemer, Targeting mitochondrial apoptosis by betulinic acid in human cancers, Drug Discov. Today 14 (2009) 885-890.

[54] S. Fulda, K.M. Debatin, Betulinic acid induces apoptosis through a direct effect on mitochondria in neuroectodermal tumors, Med. Pediatr. Oncol. 35 (2000) 616-618.

[55] G.I. Salti, J.V. Kichina, T.K. Das Gupta, S. Uddin, L. Bratescu, J.M. Pezzuto, R.G Mehta, A.I. Constantinou, Betulinic acid reduces ultraviolet-C-induced DNA breakage in congenital melanocytic naeval cells: evidence for a potential role as a chemopreventive agent, Melanoma Res. 11 (2001) 99-104.

[56] R.D. Meng, W.S. El-Deiry, P53-independent upregulation of KILLER/DR5 TRAIL receptor expression by glucocorticoids and interferon-gamma, Exp. Cell Res. 262 (2001) 154-169.

[57] E. Selzer, E. Pimentel, V. Wacheck, W. Schlegel, H. Pehamberger, B. Jansen, R. Kodym, Effects of betulinic acid alone and in combination with irradiation in human melanoma cells, J. Invest. Dermatol. 114 (2000) 935-940.

[58] W. Wick, C. Grimmel, B. Wagenknecht, J. Dichgans, M. Weller, Betulinic acidinduced apoptosis in glioma cells: a sequential requirement for new protein synthesis, formation of reactive oxygen species, and caspase processing, J. Pharmacol. Exp. Ther. 289 (1999) 1306-1312.

[59] S. Fulda, I. Jeremias, K.M. Debatin, Cooperation of betulinic acid and TRAIL to induce apoptosis in tumor cells, Oncogene 23 (2004) 7611-7620.

[60] S. Fulda, K.M. Debatin, Sensitization for anticancer drug-induced apoptosis by betulinic acid, Neoplasia 7 (2005) 162-170.

[61] T. Honda, K.T. Liby, X. Su, C. Sundararajan, Y. Honda, N. Suh, R. Risingsong, C.R. Williams, D.B. Royce, M.B. Sporn, G.W. Gribble, Design, synthesis, and antiinflammatory activity both in vitro and in vivo of new betulinic acid analogues having an enone functionality in ring A, Bioorg. Med. Chem. Lett 16 (2006) 6306-6309.

[62] Y. Fukuda, K. Sakai, S. Matsunaga, H. Tokuda, R. Tanaka, Cancer chemopreventive effect of orally administrated lupane-type triterpenoid on ultraviolet light B induced photocarcinogenesis of hairless mouse, Cance Lett. 240 (2006) 94-101.

[63] M. Willmann, V. Wacheck, J. Buckley, K. Nagy, J. Thalhammer, R. Paschke, T. Triche, B. Jansen, E. Selzer, Characterization of NVX-207, a novel betulinic acid-derived anti-cancer compound, Eur. J. Clin. Invest. 39 (2009) 384-394.

[64] B.B. Aggarwal, H. Ichikawa, P. Garodia, P. Weerasinghe, G. Sethi, I.D. Bhatt, M.K. Pandey, S. Shishodia, M.G. Nair, From traditional Ayurvedic medicine to modern medicine: identification of therapeutic targets for suppression of inflammation and cancer, Expert Opin. Ther. Targets 10 (2006) 87-118.

[65] E.R. Sailer, L.R. Subramanian, B. Rall, R.F. Hoernlein, H.P. Ammon, H. Safayhi, Acetyl-11-keto-beta-boswellic acid (AKBA): structure requirements for binding and 5-lipoxygenase inhibitory activity, Br. J. Pharmacol. 117 (1996) 615-618.

[66] J.J. Liu, A. Nilsson, S. Oredsson, V. Badmaev, W.Z. Zhao, R.D. Duan, Boswellic acids trigger apoptosis via a pathway dependent on caspase- 8 activation but independent on Fas/Fas ligand interaction in colon cancer HT-29 cells, Carcinogenesis 23 (2002) 2087-2093.

[67] A.B. Kunnumakkara, A.S. Nair, B. Sung, M.K. Pandey, B.B. Aggarwal, Boswellic acid blocks signal transducers and activators of transcription 3 signaling proliferation, and survival of multiple myeloma via the protein tyrosine phosphatase SHP-1, Mol. Cancer Res.: MCR 7 (2009) 118-128.
[68] V.R. Yadav, S. Prasad, B. Sung, R. Kannappan, B.B. Aggarwal, Targeting inflammatory pathways by triterpenoids for prevention and treatment of cancer, Toxins (Basel) 2 (2010) 2428-2466.

[69] C. Anthoni, M.G. Laukoetter, E. Rijcken, T. Vowinkel, R. Mennigen, S. Muller, N. Senninger, J. Russell, J. Jauch, J. Bergmann, D.N. Granger, C.F. Krieglstein, Mechanisms underlying the anti-inflammatory actions of boswellic acid derivatives in experimental colitis, Am. J. Physiol. Gastrointest. Liver Physiol. 290 (2006) G1131-G1137.

[70] P.R. Kiela, A.J. Midura, N. Kuscuoglu, S.D. Jolad, A.M. Solyom, D.G. Besselsen, B.N. Timmermann, F.K. Ghishan, Effects of Boswellia serrata in mouse models of chemically induced colitis, Am. J. Physiol. Gastrointest. Liver Physiol. 288 (2005) G798-G808.

[71] Y. Takada, H. Ichikawa, V. Badmaev, B.B. Aggarwal, Acetyl-11-keto-betaboswellic acid potentiates apoptosis, inhibits invasion, and abolishes osteoclastogenesis by suppressing NF-kappa B and NF-kappa B-regulated gene expression, J. Immunol. 176 (2006) 3127-3140.

[72] T. Syrovets, B. Buchele, C. Krauss, Y. Laumonnier, T. Simmet, Acetyl-boswellic acids inhibit lipopolysaccharide-mediated TNF-alpha induction in monocytes by direct interaction with IkappaB kinases, J. Immunol 174 (2005) 498-506.

[73] S.S. Agrawal, S. Saraswati, R. Mathur, M. Pandey, Antitumor properties of Boswellic acid against Ehrlich ascites cells bearing mouse, Food Chem. Toxicol.: Int. J. Publish. Br. Indust. Biol. Res. Assoc. 49 (2011) 1924-1934.

[74] S. Khan, R. Chib, B.A. Shah, Z.A. Wani, N. Dhar, D.M. Mondhe, S. Lattoo, S.K. Jain, S.C. Taneja, J. Singh, A cyano analogue of boswellic acid induces crosstalk between p53/PUMA/Bax and telomerase that stages the human papillomavirus type 18 positive HeLa cells to apoptotic death, Eur. J. Pharmacol. 660 (2011) 241-248.

[75] G. Chashoo, S.K. Singh, P.R. Sharma, D.M. Mondhe, A. Hamid, A. Saxena, S.S. Andotra, B.A. Shah, N.A. Qazi, S.C. Taneja, A.K. Saxena, A propionyloxy derivative of 11-keto-beta-boswellic acid induces apoptosis in HL-60 cells mediated through topoisomerase I \& II inhibition, Chem. Biol. Interact. 189 (2011) 60-71.

[76] X. Pang, Z. Yi, X. Zhang, B. Sung, W. Qu, X. Lian, B.B. Aggarwal, M. Liu, Acetyl11-keto-beta-boswellic acid inhibits prostate tumor growth by suppressing vascular endothelial growth factor receptor 2-mediated angiogenesis, Cancer Res. 69 (2009) 5893-5900.

[77] B.A. Shah, A. Kumar, P. Gupta, M. Sharma, V.K. Sethi, A.K. Saxena, J. Singh, G.N Qazi, S.C. Taneja, Cytotoxic and apoptotic activities of novel amino analogues of boswellic acids, Bioorg. Med. Chem. Lett. 17 (2007) 6411-6416.

78] J.J. Liu, B. Huang, S.C. Hooi, Acetyl-keto-beta-boswellic acid inhibits cellular proliferation through a p21-dependent pathway in colon cancer cells, Br. J. Pharmacol. 148 (2006) 1099-1107.

[79] T. Syrovets, B. Buchele, E. Gedig, J.R. Slupsky, T. Simmet, Acetyl-boswellic acids are novel catalytic inhibitors of human topoisomerases I and Ilalpha, Mol. Pharmacol. 58 (2000) 71-81.

[80] S. Singh, A. Khajuria, S.C. Taneja, R.K. Johri, J. Singh, G.N. Qazi, Boswellic acids: a leukotriene inhibitor also effective through topical application in inflammatory disorders, Phytomed.: Int. J. Phytother. Phytopharmacol. 15 (2008) 400-407.

[81] A. Moussaieff, R. Mechoulam, Boswellia resin: from religious ceremonies to medical uses; a review of in-vitro, in-vivo and clinical trials, J. Pharm. Pharmacol. 61 (2009) 1281-1293.

[82] H. Wang, T. Syrovets, D. Kess, B. Buchele, H. Hainzl, O. Lunov, J.M. Weiss, K. Scharffetter-Kochanek, T. Simmet, Targeting NF-kappa B with a natura triterpenoid alleviates skin inflammation in a mouse model of psoriasis, J. Immunol. 183 (2009) 4755-4763.

[83] G. Sethi, K.S. Ahn, M.K. Pandey, B.B. Aggarwal, Celastrol, a novel triterpene, potentiates TNF-induced apoptosis and suppresses invasion of tumor cells by inhibiting NF-kappaB-regulated gene products and TAK1-mediated NFkappaB activation, Blood 109 (2007) 2727-2735.

84] M.F. He, L. Liu, W. Ge, P.C. Shaw, R. Jiang, LW. Wu, P.P. But, Antiangiogenic activity of Tripterygium wilfordii and its terpenoids, J. Ethnopharmacol. 121 (2009) 61-68

[85] A. Salminen, M. Lehtonen, T. Paimela, K. Kaarniranta, Celastrol: molecular targets of Thunder God Vine, Biochem. Biophys. Res. Commun. 394 (2010) 439-442.

[86] X. Wu, V.C. Lee, E. Chevalier, S.T. Hwang, Chemokine receptors as targets for cancer therapy, Curr. Pharm. Des. 15 (2009) 742-757.

[87] X. Pang, Z. Yi, J. Zhang, B. Lu, B. Sung, W. Qu, B.B. Aggarwal, M. Liu, Celastrol suppresses angiogenesis-mediated tumor growth through inhibition of AKT/ mammalian target of rapamycin pathway, Cancer Res. 70 (2010) 1951-1959.

[88] B. Sung, B. Park, V.R. Yadav, B.B. Aggarwal, Celastrol, a triterpene, enhances TRAIL-induced apoptosis through the down-regulation of cell survival proteins and up-regulation of death receptors, J. Biol. Chem. 285 (2010) 11498-11507.

[89] D. Zhang, L. Xu, F. Cao, T. Wei, C. Yang, G. Uzan, B. Peng, Celastrol regulates multiple nuclear transcription factors belonging to HSP90's clients in a doseand cell type-dependent way, Cell Stress Chaperones 15 (2010) 939-946.

[90] H. Zhu, W.J. Ding, R. Wu, Q.J. Weng, J.S. Lou, R.J. Jin, W. Lu, B. Yang, Q.J. He, Synergistic anti-cancer activity by the combination of TRAIL/APO-2L and celastrol, Cancer Invest. 28 (2010) 23-32.

[91] H. Zhu, X.W. Liu, W.J. Ding, D.Q. Xu, Y.C. Zhao, W. Lu, Q.J. He, B. Yang, Upregulation of death receptor 4 and 5 by celastrol enhances the anti-cancer activity of TRAIL/Apo-2L, Cancer Lett. 297 (2010) 155-164.

[92] R. Kannaiyan, K.A. Manu, L. Chen, F. Li, P. Rajendran, A. Subramaniam, P. Lam, A.P. Kumar, G. Sethi, Celastrol inhibits tumor cell proliferation and promotes 
apoptosis through the activation of c-Jun N-terminal kinase and suppression of PI3 K/Akt signaling pathways, Apoptosis: Int. J. Program. Cell Death 16 (2011) 1028-1041.

[93] H. Yang, D. Chen, Q.C. Cui, X. Yuan, Q.P. Dou, Celastrol, a triterpene extracted from the Chinese "Thunder of God Vine", is a potent proteasome inhibitor and suppresses human prostate cancer growth in nude mice, Cancer Res. 66 (2006) 4758-4765.

[94] M. Nagase, J. Oto, S. Sugiyama, K. Yube, Y. Takaishi, N. Sakato, Apoptosis induction in HL-60 cells and inhibition of topoisomerase II by triterpene celastrol, Biosci. Biotechnol. Biochem. 67 (2003) 1883-1887.

[95] R. Kannaiyan, H.S. Hay, P. Rajendran, F. Li, M.K. Shanmugam, S. Vali, T. Abbasi, S. Kapoor, A. Sharma, A.P. Kumar, W.J. Chng, G. Sethi, Celastrol inhibits proliferation and induces chemosensitization through down-regulation of NF-kappaB and STAT3 regulated gene products in multiple myeloma cells, $\mathrm{Br}$. J. Pharmacol. 164 (2011) 1506-1521.

[96] Y. Huang, Y. Zhou, Y. Fan, D. Zhou, Celastrol inhibits the growth of human glioma xenografts in nude mice through suppressing VEGFR expression, Cancer Lett. 264 (2008) 101-106.

[97] Z. Lu, Y. Jin, L. Qiu, Y. Lai, J. Pan, Celastrol, a novel HSP90 inhibitor, depletes Bcr-Abl and induces apoptosis in imatinib-resistant chronic myelogenous leukemia cells harboring T315I mutation, Cancer Lett. 290 (2010) $182-191$.

[98] S.D. Westerheide, J.D. Bosman, B.N. Mbadugha, T.L. Kawahara, G. Matsumoto, S. Kim, W. Gu, J.P. Devlin, R.B. Silverman, R.I. Morimoto, Celastrols as inducers of the heat shock response and cytoprotection, J. Biol. Chem. 279 (2004) 56053-56060.

[99] T. Zhang, A. Hamza, X. Cao, B. Wang, S. Yu, C.G. Zhan, D. Sun, A novel Hsp90 inhibitor to disrupt Hsp90/Cdc37 complex against pancreatic cancer cells, Mol. Cancer Ther. 7 (2008) 162-170.

[100] Y. Kim, K. Kim, H. Lee, S. Han, Y.S. Lee, J. Choe, Y.M. Kim, J.H. Hahn, J.Y. Ro, D. Jeoung, Celastrol binds to ERK and inhibits FcepsilonRI signaling to exert an anti-allergic effect, Eur. J. Pharmacol. 612 (2009) 131-142.

[101] H. Hieronymus, J. Lamb, K.N. Ross, X.P. Peng C. Clement, A. Rodina, M. Nieto, J. Du, K. Stegmaier, S.M. Raj, K.N. Maloney, J. Clardy, W.C. Hahn, G. Chiosis, T.R. Golub, Gene expression signature-based chemical genomic prediction identifies a novel class of HSP90 pathway modulators, Cancer Cell 10 (2006) $321-330$.

[102] S. Abbas, A. Bhoumik, R. Dahl, S. Vasile, S. Krajewski, N.D. Cosford, Z.A. Ronai, Preclinical studies of celastrol and acetyl isogambogic acid in melanoma, Clin. Cancer Res. 13 (2007) 6769-6778.

[103] S.M. Raja, R.J. Clubb, C. Ortega-Cava, S.H. Williams, T.A. Bailey, L. Duan, X. Zhao, A.L. Reddi, A.M. Nyong, A. Natarajan, V. Band, H. Band, Anticancer activity of Celastrol in combination with ErbB2-targeted therapeutics for treatment of ErbB2-overexpressing breast cancers, Cancer Biol. Ther. 11 (2011) 263-276.

[104] H. Zhu, X.W. Liu, T.Y. Cai, J. Cao, C.X. Tu, W. Lu, Q.J. He, B. Yang, Celastrol acts as a potent antimetastatic agent targeting beta1 integrin and inhibiting cellextracellular matrix adhesion, in part via the p38 mitogen-activated protein kinase pathway, J. Pharmacol. Exp. Ther. 334 (2010) 489-499.

[105] H. Matsuda, Y. Li, T. Murakami, K. Ninomiya, J. Yamahara, M. Yoshikawa, Effects of escins Ia, Ib, IIa, and IIb from horse chestnut, the seeds of Aesculus hippocastanum L., on acute inflammation in animals, Biol. Pharm. Bull. 20 (1997) 1092-1095.

[106] M. Rothkopf, G. Vogel, New findings on the efficacy and mode of action of the horse chestnut saponin escin, Arzneimittelforschung 26 (1976) 225-235.

[107] H. Matsuda, T. Murakami, Y. Li, J. Yamahara, M. Yoshikawa, Mode of action of escins Ia and IIa and E, Z-senegin II on glucose absorption in gastrointestinal tract, Bioorg. Med. Chem. 6 (1998) 1019-1023.

[108] J.M. Patlolla, J. Raju, M.V. Swamy, C.V. Rao, Beta-escin inhibits colonic aberrant crypt foci formation in rats and regulates the cell cycle growth by inducing p21(waf1/cip1) in colon cancer cells, Mol. Cancer Ther. 5 (2006) 1459-1466

[109] K.B. Harikumar, B. Sung, M.K. Pandey, S. Guha, S. Krishnan, B.B. Aggarwal, Escin, a pentacyclic triterpene, chemosensitizes human tumor cells through inhibition of nuclear factor-kappaB signaling pathway, Mol. Pharmacol. 77 (2010) 818-827.

[110] Y.P. Niu, L.D. Li, L.M. Wu, Beta-aescin: a potent natural inhibitor of proliferation and inducer of apoptosis in human chronic myeloid leukemia K562 cells in vitro, Leuk. Lymphoma 49 (2008) 1384-1391.

[111] Y.P. Niu, L.M. Wu, Y.L. Jiang, W.X. Wang, L.D. Li, Beta-escin, a natural triterpenoid saponin from Chinese horse chestnut seeds, depresses HL-60 human leukaemia cell proliferation and induces apoptosis, J. Pharm. Pharmacol. 60 (2008) 1213-1220.

[112] D.Y. Shen, J.H. Kang, W. Song, W.Q Zhang, W.G. Li, Y. Zhao, Q.X. Chen, Apoptosis of human cholangiocarcinoma cell lines induced by beta-escin through mitochondrial caspase-dependent pathway. Phytother. Res., 2011.

[113] X.Y. Zhou, F.H. Fu, Z. Li, QJ. Dong. J. He, C.H. Wang, Escin, a natural mixture of triterpene saponins, exhibits antitumor activity against hepatocellular carcinoma, Planta Med. 75 (2009) 1580-1585.

[114] S.M. Tan, F. Li, P. Rajendran, A.P. Kumar, K.M. Hui, G. Sethi, Identification of beta-escin as a novel inhibitor of signal transducer and activator of transcription 3/Janus-activated kinase 2 signaling pathway that suppresses proliferation and induces apoptosis in human hepatocellular carcinoma cells, J. Pharmacol. Exp. Ther. 334 (2010) 285-293.
[115] Z.J. Ming, Y. Hu, Y.H. Qiu, L. Cao, X.G. Zhang, Synergistic effects of beta-aescin and 5-fluorouracil in human hepatocellular carcinoma SMMC-7721 cells, Phytomedicine 17 (2010) 575-580.

[116] X.M. Hu, Y. Zhang, F.D. Zeng, Effects of beta-aescin on apoptosis induced by transient focal cerebral ischemia in rats, Acta Pharmacol. Sinica 25 (2004) 1267-1275.

[117] M. Montopoli, G. Froldi, M.C. Comelli, M. Prosdocimi, L. Caparrotta, Aescin protection of human vascular endothelial cells exposed to cobalt chloride mimicked hypoxia and inflammatory stimuli, Planta Med. 73 (2007) 285288.

[118] D.B. Ji, B. Xu, J.T. Liu, F.X. Ran, J.R. Cui, Beta-escin sodium inhibits inducible nitric oxide synthase expression via downregulation of the JAK/STAT pathway in A549 cells, Mol. Carcinog, 2011.

[119] X.H. Wang, B. Xu, J.T. Liu, J.R. Cui, Effect of beta-escin sodium on endothelial cells proliferation, migration and apoptosis, Vascul. Pharmacol. 49 (2008) $158-165$.

[120] W. Xin, L. Zhang, F. Sun, N. Jiang, H. Fan, T. Wang, Z. Li, J. He, F. Fu, Escin exerts synergistic anti-inflammatory effects with low doses of glucocorticoids in vivo and in vitro, Phytomedicine 18 (2011) 272-277.

[121] M.N. Asl, H. Hosseinzadeh, Review of pharmacological effects of Glycyrrhiza sp. and its bioactive compounds, Phytother. Res. 22 (2008) 709-724.

[122] H. Hibasami, H. Iwase, K. Yoshioka, H. Takahashi, Glycyrrhizin induces apoptosis in human stomach cancer KATO III and human promyelotic leukemia HL-60 cells, Int. J. Mol. Med. 16 (2005) 233-236.

[123] T. Rossi, M. Castelli, G. Zandomeneghi, A. Ruberto, L. Benassi, C. Magnoni, S Santachiara, G. Baggio, Selectivity of action of glycyrrhizin derivatives on the growth of MCF-7 and HEP-2 cells, Anticancer Res. 23 (2003) 3813-3818.

[124] T. Rossi, L. Benassi, C. Magnoni, A.I. Ruberto, A. Coppi, G. Baggio, Effects of glycyrrhizin on UVB-irradiated melanoma cells, In Vivo 19 (2005) 319-322.

[125] G. Sharma, S. Kar, S. Palit, P.K. Das, 18beta-Glycyrrhetinic acid induces apoptosis through modulation of Akt/FOXO3a/Bim pathway in human breast cancer MCF-7 cells. J. Cell Physiol., 2011.

[126] C.S. Lee, Y.J. Kim, M.S. Lee, E.S. Han, S.J. Lee, 18beta-Glycyrrhetinic acid induces apoptotic cell death in SiHa cells and exhibits a synergistic effect against antibiotic anti-cancer drug toxicity, Life Sci. 83 (2008) 481-489.

[127] Y. Satomi, H. Nishino, S. Shibata, Glycyrrhetinic acid and related compounds induce G1 arrest and apoptosis in human hepatocellular carcinoma HepG2, Anticancer Res. 25 (2005) 4043-4047.

[128] S. Chintharlapalli, S. Papineni, I. Jutooru, A. McAlees, S. Safe, Structuredependent activity of glycyrrhetinic acid derivatives as peroxisome proliferator-activated receptor gamma agonists in colon cancer cells, Mol. Cancer Ther. 6 (2007) 1588-1598.

[129] C.Y. Hsiang, I.L. Lai, D.C. Chao, T.Y. Ho, Differential regulation of activator protein 1 activity by glycyrrhizin, Life Sci. 70 (2002) 1643-1656.

[130] K. Niwa, Z. Lian, K. Onogi, W. Yun, L. Tang H. Mori, T. Tamaya, Preventive effects of glycyrrhizin on estrogen-related endometrial carcinogenesis in mice, Oncol. Rep. 17 (2007) 617-622.

131] J.M. Cherng, K.D. Tsai, Y.W. Yu, J.C. Lin, Molecular mechanisms underlying chemopreventive activities of glycyrrhizic acid against UVB-radiationinduced carcinogenesis in SKH-1 hairless mouse epidermis, Radiat. Res. 176 (2011) 177-186

[132] T.J. Raphael, G. Kuttan, Effect of naturally occurring triterpenoids ursolic acid and glycyrrhizic acid on the cell-mediated immune responses of metastatic tumor-bearing animals, Immunopharmacol. Immunotoxicol. 30 (2008) 243255.

[133] M. Saleem, Lupeol, a novel anti-inflammatory and anti-cancer dietary triterpene, Cancer Lett. 285 (2009) 109-115.

[134] M. Saleem, F. Afaq, V.M. Adhami, H. Mukhtar, Lupeol modulates NF-kappaB and PI3K/Akt pathways and inhibits skin cancer in CD-1 mice, Oncogene 23 (2004) 5203-5214.

[135] T.K. Lee, R.T. Poon, J.Y. Wo, S. Ma, X.Y. Guan, J.N. Myers, P. Altevogt, A.P. Yuen, Lupeol suppresses cisplatin-induced nuclear factor-kappaB activation in head and neck squamous cell carcinoma and inhibits local invasion and nodal metastasis in an orthotopic nude mouse model, Cancer Res. 67 (2007) 88008809.

136] M.A. Fernandez, B. de las Heras, M.D. Garcia, M.T Saenz, A. Villar, New insights into the mechanism of action of the anti-inflammatory triterpene lupeol, J. Pharm Pharmacol. 53 (2001) 1533-1539.

[137] S. Prasad, E. Madan, N. Nigam, P. Roy, J. George, Y. Shukla, Induction of apoptosis by lupeol in human epidermoid carcinoma A431 cells through regulation of mitochondrial, Akt/PKB and NFkappaB signaling pathways, Cancer Biol. Ther. 8 (2009) 1632-1639.

[138] H.R. Siddique, M. Saleem, Beneficial health effects of lupeol triterpene: a review of preclinical studies, Life Sci. 88 (2011) 285-293.

[139] H.R. Siddique, S.K. Mishra, R.J. Karnes, M. Saleem, Lupeol, a novel androgen receptor inhibitor: implications in prostate cancer therapy, Clin. Cancer Res. 17 (2011) 5379-5391.

[140] M. Saleem, N. Maddodi, M. Abu Zaid, N. Khan, B. bin Hafeez, M. Asim, Y. Suh, J.M. Yun, V. Setaluri, H. Mukhtar, Lupeol inhibits growth of highly aggressive human metastatic melanoma cells in vitro and in vivo by inducing apoptosis, Clin. Cancer Res. 14 (2008) 2119-2127.

[141] M. Saleem, I. Murtaza, R.S. Tarapore, Y. Suh, V.M. Adhami, J.J. Johnson, I.A Siddiqui, N. Khan, M. Asim, B.B. Hafeez, M.T. Shekhani, B. Li, H. Mukhtar, 
Lupeol inhibits proliferation of human prostate cancer cells by targeting beta-catenin signaling, Carcinogenesis 30 (2009) 808-817.

[142] M. Saleem, I. Murtaza, O. Witkowsky, A.M. Kohl, N. Maddodi, Lupeol triterpene, a novel diet-based microtubule targeting agent: disrupts survivin/cFLIP activation in prostate cancer cells, Biochem. Biophys. Res. Commun. 388 (2009) 576-582.

[143] R.S. Tarapore, I.A. Siddiqui, M. Saleem, V.M. Adhami, V.S. Spiegelman, H Mukhtar, Specific targeting of Wnt/beta-catenin signaling in human melanoma cells by a dietary triterpene lupeol, Carcinogenesis 31 (2010) 1844-1853.

[144] I. Murtaza, M. Saleem, V.M. Adhami, B.B. Hafeez, H. Mukhtar, Suppression of cFLIP by lupeol, a dietary triterpene, is sufficient to overcome resistance to TRAIL-mediated apoptosis in chemoresistant human pancreatic cancer cells, Cancer Res. 69 (2009) 1156-1165.

[145] N. Khan, F. Afaq, H. Mukhtar, Cancer chemoprevention through dietary antioxidants: progress and promise, Antioxid. Redox Signal. 10 (2008) 475510.

[146] T.K. Lee, A. Castilho, V.C. Cheung, K.H. Tang, S. Ma, I.O. Ng, Lupeol targets liver tumor-initiating cells through phosphatase and tensin homolog modulation, Hepatology 53 (2011) 160-170.

[147] T. Oguro, J. Liu, C.D. Klaassen, T. Yoshida, Inhibitory effect of oleanolic acid on 12-O-tetradecanoylphorbol-13-acetate-induced gene expression in mouse skin, Toxicol. Sci. 45 (1998) 88-93.

[148] P. Zhang, H. Li, D. Chen, J. Ni, Y. Kang, S. Wang, Oleanolic acid induces apoptosis in human leukemia cells through caspase activation and poly(ADPribose) polymerase cleavage, Acta Biochim. Biophys. Sinica (Shanghai) 39 (2007) 803-809.

[149] M. Fukumura, H. Ando, Y. Hirai, K. Toriizuka, Y. Ida, Y. Kuchino Achyranthoside $\mathrm{H}$ methyl ester, a novel oleanolic acid saponin derivative from Achyranthes fauriei roots, induces apoptosis in human breast cance MCF-7 and MDA-MB-453 cells via a caspase activation pathway, J. Nat. Med 63 (2009) 181-188.

[150] M.E. Juan, J.M. Planas, V. Ruiz-Gutierrez, H. Daniel, U. Wenzel, Antiproliferative and apoptosis-inducing effects of maslinic and oleanolic acids, two pentacyclic triterpenes from olives, on HT-29 colon cancer cells, Br. J. Nutr. 100 (2008) 36-43.

[151] N.B. Janakiram, C. Indranie, S.V. Malisetty, P. Jagan, V.E. Steele, C.V. Rao, Chemoprevention of colon carcinogenesis by oleanolic acid and its analog in male F344 rats and modulation of COX-2 and apoptosis in human colon HT29 cancer cells, Pharm Res. 25 (2008) 2151-2157.

[152] M.J. Jung, Y.C. Yoo, K.B. Lee, J.B. Kim, K.S. Song, Isolation of epi-oleanolic acid from Korean mistletoe and its apoptosis-lnducing activity in tumor cells Arch Pharm Res. 27 (2004) 840-844.

[153] A. Bishayee, S. Ahmed, N. Brankov, M. Perloff, Triterpenoids as potential agents for the chemoprevention and therapy of breast cancer, Front Biosci. 16 (2011) 980-996.

[154] R. Chu, X. Zhao, C. Griffin, R.E. Staub, M. Shoemaker, J. Climent, D. Leitman, Cohen, E. Shtivelman, S. Fong, Selective concomitant inhibition of mTORC1 and mTORC2 activity in estrogen receptor negative breast cancer cells by BN107 and oleanolic acid, Int. J. Cancer 127 (2010) 1209-1219.

[155] D. Deeb, X. Gao, H. Jiang, B. Janic, A.S. Arbab, Y. Rojanasakul, S.A. Dulchavsky, S.C. Gautam, Oleanane triterpenoid CDDO-Me inhibits growth and induces apoptosis in prostate cancer cells through a ROS-dependent mechanism, Biochem. Pharmacol. 79 (2010) 350-360.

[156] S.L. Yan, C.Y. Huang, S.T. Wu, M.C. Yin, Oleanolic acid and ursolic acid induce apoptosis in four human liver cancer cell lines, Toxicol. In Vitro 24 (2010) 842-848.

[157] M. Konopleva, T. Tsao, Z. Estrov, R.M. Lee, R.Y. Wang, C.E. Jackson, T. McQueen, G. Monaco, M. Munsell, J. Belmont, H. Kantarjian, M.B. Sporn, M. Andreeff, The synthetic triterpenoid 2-cyano-3,12-dioxooleana-1,9-dien-28oic acid induces caspase-dependent and -independent apoptosis in acute myelogenous leukemia, Cancer Res. 64 (2004) 7927-7935.

[158] Z. Ovesna, A. Vachalkova, K. Horvathova, D. Tothova, Pentacyclic triterpenoic acids: new chemoprotective compounds, Minireview. Neoplasma 51 (2004) 327-333.

[159] W. Zou, X. Liu, P. Yue, Z. Zhou, M.B. Sporn, R. Lotan, F.R. Khuri, S.Y. Sun, C-Jun $\mathrm{NH} 2$-terminal kinase-mediated up-regulation of death receptor 5 contributes to induction of apoptosis by the novel synthetic triterpenoid methyl-2 cyano-3,12-dioxooleana-1, 9-dien-28-oate in human lung cancer cells, Cancer Res. 64 (2004) 7570-7578.

[160] A.T. Dinkova-Kostova, K.T. Liby, K.K. Stephenson, W.D. Holtzclaw, X. Gao, N Suh, C. Williams, R. Risingsong, T. Honda, G.W. Gribble, M.B. Sporn, P. Talalay, Extremely potent triterpenoid inducers of the phase 2 response: correlations of protection against oxidant and inflammatory stress, Proc. Natl. Acad. Sci. USA 102 (2005) 4584-4589.

[161] A.L. Eggler, K.A. Gay, A.D. Mesecar, Molecular mechanisms of natural products in chemoprevention: induction of cytoprotective enzymes by Nrf2, Mol. Nutr. Food Res. 52 (Suppl. 1) (2008) S84-S94.

[162] A.E. Place, N. Suh, C.R. Williams, R. Risingsong, T. Honda, Y. Honda, G.W. Gribble, L.M. Leesnitzer, J.B. Stimmel, T.M. Willson, E. Rosen, M.B. Sporn, The novel synthetic triterpenoid, CDDO-imidazolide, inhibits inflammatory response and tumor growth in vivo, Clin. Cancer Res. 9 (2003) 2798-2806.

[163] S. Shishodia, G. Sethi, M. Konopleva, M. Andreeff, B.B. Aggarwal, A synthetic triterpenoid, CDDO-Me, inhibits IkappaBalpha kinase and enhances apoptosis induced by TNF and chemotherapeutic agents through down-regulation of expression of nuclear factor kappaB-regulated gene products in human leukemic cells, Clin. Cancer Res. 12 (2006) 1828-1838.

[164] R. Ahmad, D. Raina, C. Meyer, S. Kharbanda, D. Kufe, Triterpenoid CDDO-Me blocks the NF-kappaB pathway by direct inhibition of IKKbeta on Cys-179, J. Biol. Chem. 281 (2006) 35764-35769.

[165] R. Ahmad, D. Raina, C. Meyer, D. Kufe, Triterpenoid CDDO-methyl ester inhibits the Janus-activated kinase- $1 \quad(J A K 1) \rightarrow$ signal transducer and activator of transcription-3 (STAT3) pathway by direct inhibition of JAK1 and STAT3, Cancer Res. 68 (2008) 2920-2926.

[166] M.M. Yore, K.T. Liby, T. Honda, G.W. Gribble, M.B. Sporn, The synthetic triterpenoid 1-[2-cyano-3,12-dioxooleana-1,9(11)-dien-28-oyl]imidazole blocks nuclear factor-kappaB activation through direct inhibition of IkappaB kinase beta, Mol. Cancer Ther. 5 (2006) 3232-3239.

[167] K.H. Sohn, H.Y. Lee, H.Y. Chung, H.S. Young, S.Y. Yi, K.W. Kim, Anti-angiogenic activity of triterpene acids, Cancer Lett. 94 (1995) 213-218.

[168] I. Sogno, N. Vannini, G. Lorusso, R. Cammarota, D.M. Noonan, L. Generoso, M.B. Sporn, A. Albini, Anti-angiogenic activity of a novel class of chemopreventive compounds: oleanic acid terpenoids, Recent Results Cancer Res. 181 (2009) 209-212.

[169] J. Liu, Pharmacology of oleanolic acid and ursolic acid, J. Ethnopharmacol. 49 (1995) 57-68

[170] X. He, R.H. Liu, Cranberry phytochemicals: isolation, structure elucidation, and their antiproliferative and antioxidant activities, J. Agric. Food Chem. 54 (2006) 7069-7074.

[171] D.K. Kim, J.H. Baek, C.M. Kang, M.A. Yoo, J.W. Sung, H.Y. Chung, N.D. Kim, Y.H. Choi, S.H. Lee, K.W. Kim, Apoptotic activity of ursolic acid may correlate with the inhibition of initiation of DNA replication, Int. J. Cancer 87 (2000) 629636

[172] J.H. Baek, Y.S. Lee, C.M. Kang, J.A. Kim, K.S. Kwon, H.C. Son, K.W. Kim, Intracellular $\mathrm{Ca}^{2+}$ release mediates ursolic acid-induced apoptosis in human leukemic HL-60 cells, Int. J. Cancer 73 (1997) 725-728.

[173] X.S. Liu, J. Jiang, Induction of apoptosis and regulation of the MAPK pathway by ursolic acid in human leukemia K562 cells, Planta Med. 73 (2007) 11921194.

[174] Y. Achiwa, K. Hasegawa, Y. Udagawa, Molecular mechanism of ursolic acid induced apoptosis in poorly differentiated endometrial cancer HEC108 cells, Oncol. Rep. 14 (2005) 507-512.

[175] Y. Achiwa, K. Hasegawa, T. Komiya, Y. Udagawa, Ursolic acid induces Baxdependent apoptosis through the caspase- 3 pathway in endometrial cancer SNG-II cells, Oncol. Rep. 13 (2005) 51-57.

[176] P.O. Harmand, R. Duval, C. Delage, A. Simon, Ursolic acid induces apoptosis through mitochondrial intrinsic pathway and caspase-3 activation in M4Beu melanoma cells, Int. J. Cancer 114 (2005) 1-11.

[177] Y.L. Hsu, P.L. Kuo, C.C. Lin, Proliferative inhibition, cell-cycle dysregulation, and induction of apoptosis by ursolic acid in human non-small cell lung cancer A549 cells, Life Sci. 75 (2004) 2303-2316.

[178] E. Kassi, Z. Papoutsi, H. Pratsinis, N. Aligiannis, M. Manoussakis, P. Moutsatsou, Ursolic acid, a naturally occurring triterpenoid, demonstrates anticancer activity on human prostate cancer cells, J. Cancer Res. Clin. Oncol. 133 (2007) 493-500.

[179] P.O. Harmand, R. Duval, B. Liagre, C. Jayat-Vignoles, J.L. Beneytout, C. Delage A. Simon, Ursolic acid induces apoptosis through caspase-3 activation and cell cycle arrest in HaCat cells, Int. J. Oncol. 23 (2003) 105-112.

[180] F. Lauthier, L. Taillet, P. Trouillas, C. Delage, A. Simon, Ursolic acid triggers calcium-dependent apoptosis in human Daudi cells, Anticancer Drugs 11 (2000) 737-745

[181] Y.H. Choi, J.H. Baek, M.A. Yoo, H.Y. Chung, N.D. Kim, K.W. Kim, Induction of apoptosis by ursolic acid through activation of caspases and down-regulation of c-IAPs in human prostate epithelial cells, Int. J. Oncol. 17 (2000) 565-571.

[182] F. Hollosy, M. Idei, G. Csorba, E. Szabo, G. Bokonyi, A. Seprodi, G. Meszaros, B Szende, G. Keri, Activation of caspase-3 protease during the process of ursolic acid and its derivative-induced apoptosis, Anticancer Res. 21 (2001) 34853491.

[183] F. Hollosy, G. Meszaros, G. Bokonyi, M. Idei, A. Seprodi, B. Szende, G. Keri, Cytostatic, cytotoxic and protein tyrosine kinase inhibitory activity of ursolic acid in A431 human tumor cells, Anticancer Res. 20 (2000) $4563-4570$.

[184] S. Shishodia, S. Majumdar, S. Banerjee, B.B. Aggarwal, Ursolic acid inhibits nuclear factor-kappaB activation induced by carcinogenic agents through suppression of IkappaBalpha kinase and p65 phosphorylation: correlation with down-regulation of cyclooxygenase 2, matrix metalloproteinase 9 , and cyclin D1, Cancer Res. 63 (2003) 4375-4383.

[185] M.K. Shanmugam, P. Rajendran, F. Li, T. Nema, S. Vali, T. Abbasi, S. Kapoor, A. Sharma, A.P. Kumar, P.C. Ho, K.M. Hui, G. Sethi, Ursolic acid inhibits multiple cell survival pathways leading to suppression of growth of prostate cancer xenograft in nude mice, J. Mol. Med. (Berl) 89 (2011) 713-727.

[186] M.K. Shanmugam, K.A. Manu, T.H. Ong, L. Ramachandran, R. Surana, P. Bist, L.H. Lim, A.P. Kumar, K.M. Hui, G. Sethi, Inhibition of CXCR4/CXCL12 signaling axis by ursolic acid leads to suppression of metastasis in transgenic adenocarcinoma of mouse prostate model, Int. J. Cancer 129 (2011) 15521563.

[187] A.K. Pathak, M. Bhutani, A.S. Nair, K.S. Ahn, A. Chakraborty, H. Kadara, S. Guha, G. Sethi, B.B. Aggarwal, Ursolic acid inhibits STAT3 activation pathway leading to suppression of proliferation and chemosensitization of human multiple myeloma cells, Mol. Cancer Res. 5 (2007) 943-955. 
[188] K. Subbaramaiah, P. Michaluart, M.B. Sporn, A.J. Dannenberg, Ursolic acid inhibits cyclooxygenase-2 transcription in human mammary epithelial cells, Cancer Res. 60 (2000) 2399-2404.

[189] T. Honda, G.W. Gribble, N. Suh, H.J. Finlay, B.V. Rounds, L. Bore, F.G. Favaloro Jr., Y. Wang, M.B. Sporn, Novel synthetic oleanane and ursane triterpenoids with various enone functionalities in ring $A$ as inhibitors of nitric oxide production in mouse macrophages, J. Med. Chem. 43 (2000) 1866-1877.

[190] E.K. Yim, M.J. Lee, K.H. Lee, S.J. Um, J.S. Park, Antiproliferative and antiviral mechanisms of ursolic acid and dexamethasone in cervical carcinoma cell lines, Int. J. Gynecol. Cancer 16 (2006) 2023-2031.

[191] N. Suh, Y. Wang, T. Honda, G.W. Gribble, E. Dmitrovsky, W.F. Hickey, R.A. Maue, A.E. Place, D.M. Porter, M.J. Spinella, C.R. Williams, G. Wu, A.J. Dannenberg, K.C. Flanders, J.J. Letterio, D.J. Mangelsdorf, C.F. Nathan, L. Nguyen, W.W. Porter, R.F. Ren, A.B. Roberts, N.S. Roche, K. Subbaramaiah, M.B. Sporn, A novel synthetic oleanane triterpenoid, 2-cyano-3,12-dioxoolean-1,9dien-28-oic acid, with potent differentiating, antiproliferative, and antiinflammatory activity, Cancer Res. 59 (1999) 336-341.

[192] M.L. Hyer, R. Croxton, M. Krajewska, S. Krajewski, C.L. Kress, M. Lu, N. Suh, M.B. Sporn, V.L. Cryns, J.M. Zapata, J.C. Reed, Synthetic triterpenoids cooperate with tumor necrosis factor-related apoptosis-inducing ligand to induce apoptosis of breast cancer cells, Cancer Res. 65 (2005) 4799-4808.

[193] K. Liby, T. Hock, M.M. Yore, N. Suh, A.E. Place, R. Risingsong, C.R. Williams, D.B. Royce, T. Honda, Y. Honda, G.W. Gribble, N. Hill-Kapturczak, A. Agarwal, M.B. Sporn, The synthetic triterpenoids, CDDO and CDDO-imidazolide, are potent inducers of heme oxygenase- 1 and Nrf2/ARE signaling, Cancer Res. 65 (2005) 4789-4798.

[194] Y. Tanaka, L.M. Aleksunes, M.J. Goedken, C. Chen, S.A. Reisman, J.E. Manautou, C.D. Klaassen, Coordinated induction of Nrf2 target genes protects against iron nitrilotriacetate (FeNTA)-induced nephrotoxicity, Toxicol. Appl. Pharmacol. 231 (2008) 364-373.

[195] K. Liby, N. Voong, C.R. Williams, R. Risingsong, D.B. Royce, T. Honda, G.W. Gribble, M.B. Sporn, J.J. Letterio, The synthetic triterpenoid CDDO-Imidazolide suppresses STAT phosphorylation and induces apoptosis in myeloma and lung cancer cells, Clin. Cancer Res. 12 (2006) 4288-4293.

[196] K. Liby, R. Risingsong, D.B. Royce, C.R. Williams, M.M. Yore, T. Honda, G.W. Gribble, W.W. Lamph, N. Vannini, I. Sogno, A. Albini, M.B. Sporn, Prevention and treatment of experimental estrogen receptor-negative mammary carcinogenesis by the synthetic triterpenoid CDDO-methyl Ester and the rexinoid LG100268, Clin. Cancer Res. 14 (2008) 4556-4563.

[197] I. Pitha-Rowe, K. Liby, D. Royce, M. Sporn, Synthetic triterpenoids attenuate cytotoxic retinal injury: cross-talk between Nrf2 and PI3K/AKT signaling through inhibition of the lipid phosphatase PTEN, Invest. Ophthalmol. Vis. Sci. 50 (2009) 5339-5347.

[198] D. Deeb, X. Gao, S.A. Dulchavsky, S.C. Gautam, CDDO-me induces apoptosis and inhibits Akt, mTOR and NF-kappaB signaling proteins in prostate cancer cells, Anticancer Res. 27 (2007) 3035-3044.

[199] D. Deeb, X. Gao, H. Jiang, S.A. Dulchavsky, S.C. Gautam, Oleanane triterpenoid CDDO-Me inhibits growth and induces apoptosis in prostate cancer cells by independently targeting pro-survival Akt and mTOR, Prostate 69 (2009) 851860.

[200] M.M. Yore, A.N. Kettenbach, M.B. Sporn, S.A. Gerber, K.T. Liby, Proteomic analysis shows synthetic oleanane triterpenoid binds to mTOR, PLoS ONE 6 (2011) e22862.

[201] X. Gao, D. Deeb, P. Liu, Y. Liu, S. Arbab-Ali, S.A. Dulchavsky, S.C. Gautam, Role of reactive oxygen species (ROS) in CDDO-Me-mediated growth inhibition and apoptosis in colorectal cancer cells, J. Exp. Ther. Oncol. 9 (2011) 119-127.

[202] W. Zou, P. Yue, F.R. Khuri, S.Y. Sun, Coupling of endoplasmic reticulum stress to CDDO-Me-induced up-regulation of death receptor 5 via a CHOPdependent mechanism involving JNK activation, Cancer Res. 68 (2008) 7484-7492.

[203] R. Vene, P. Larghero, G. Arena, M.B. Sporn, A. Albini, F. Tosetti, Glycogen synthase kinase 3beta regulates cell death induced by synthetic triterpenoids, Cancer Res. 68 (2008) 6987-6996.

[204] W. Zou, S. Chen, X. Liu, P. Yue, M.B. Sporn, F.R. Khuri, S.Y. Sun, C-FLIP downregulation contributes to apoptosis induction by the novel synthetic triterpenoid methyl-2-cyano-3, 12-dioxooleana-1, 9-dien-28-oate (CDDO$\mathrm{Me}$ ) in human lung cancer cells, Cancer Biol. Ther. 6 (2007) 1614-1620.

[205] N. Vannini, G. Lorusso, R. Cammarota, M. Barberis, D.M. Noonan, M.B. Sporn, A. Albini, The synthetic oleanane triterpenoid, CDDO-methyl ester, is a potent antiangiogenic agent, Mol. Cancer Ther. 6 (2007) 3139-3146.

[206] I. Samudio, S. Kurinna, P. Ruvolo, B. Korchin, H. Kantarjian, M. Beran, K. Dunner Jr., S. Kondo, M. Andreeff, M. Konopleva, Inhibition of mitochondrial metabolism by methyl-2-cyano-3,12-dioxooleana-1,9-diene-28-oate induces apoptotic or autophagic cell death in chronic myeloid leukemia cells, Mol. Cancer Ther. 7 (2008) 1130-1139.

[207] M.L. Hyer, R. Shi, M. Krajewska, C. Meyer, I.V. Lebedeva, P.B. Fisher, J.C. Reed Apoptotic activity and mechanism of 2-cyano-3,12-dioxoolean-1,9-dien-28oic-acid and related synthetic triterpenoids in prostate cancer, Cancer Res. 68 (2008) 2927-2933.

[208] J.L. Alabran, A. Cheuk, K. Liby, M. Sporn, J. Khan, J. Letterio, K.S. Leskov, Human neuroblastoma cells rapidly enter cell cycle arrest and apoptosis following exposure to C-28 derivatives of the synthetic triterpenoid CDDO, Cancer Biol. Ther. 7 (2008) 709-717.

209] K.T. Liby, D.B. Royce, R. Risingsong C.R. Williams, A. Maitra, R.H. Hruban, M.B. Sporn, Synthetic triterpenoids prolong survival in a transgenic mouse model of pancreatic cancer, Cancer Prev. Res. (Phila) 3 (2010) 1427-1434.

210] X. Gao, D. Deeb, Y. Liu, A.S. Arbab, G.W. Divine, S.A. Dulchavsky, S.C. Gautam, Prevention of Prostate Cancer with Oleanane Synthetic Triterpenoid CDDOMe in the TRAMP Mouse Model of Prostate Cancer, Cancers (Basel) 3 (2011) 3353-3369.

[211] D. Deeb, X. Gao, Y. Liu, D. Jiang, G.W. Divine, A.S. Arbab, S.A. Dulchavsky, S.C Gautam, Synthetic triterpenoid CDDO prevents the progression and metastasis of prostate cancer in TRAMP mice by inhibiting survival signaling, Carcinogenesis 32 (2011) 757-764.

[212] E.H. Kim, C. Deng, M.B. Sporn, D.B. Royce, R. Risingsong, C.R. Williams, K.T Liby, CDDO-methyl ester delays breast cancer development in brca1-mutated mice, Cancer Prev. Res., 2011.

[213] J.J. Auletta, J.L. Alabran, B.G. Kim, C.J. Meyer, J.J. Letterio, The synthetic triterpenoid, CDDO-Me, modulates the proinflammatory response to in vivo lipopolysaccharide challenge, J. Interferon Cytokine Res. 30 (2010) 497-508.

[214] I. Jutooru, G. Chadalapaka, M. Abdelrahim, M.R. Basha, I. Samudio, M Konopleva, M. Andreeff, S. Safe, Methyl 2-cyano-3,12-dioxooleana-1,9-dien28-oate decreases specificity protein transcription factors and inhibits pancreatic tumor growth: role of microRNA-27a, Mol. Pharmacol. 78 (2010) 226-236.

[215] E.H. Kim, C.X. Deng, M.B. Sporn, K.T. Liby, CDDO-imidazolide induces DNA damage, G2/M arrest and apoptosis in BRCA1-mutated breast cancer cells, Cancer Prev. Res. 4 (2011) 425-434.

[216] A. Petronelli, E. Pelosi, S. Santoro, E. Saulle, A.M. Cerio, G. Mariani, C. Labbaye, U. Testa, CDDO-Im is a stimulator of megakaryocytic differentiation, Leuk. Res. 35 (2011) 534-544.

217] S.F. Elsawa, A.J. Novak, D. Grote, M. Konopleva, M. Andreeff, T.E. Witzig S.M. Ansell, CDDO-imidazolide mediated inhibition of malignant cell growth in Waldenstrom macroglobulinemia, Leuk. Res. 32 (2008) 1895-1902.

218] J.L. Townson, I.C. Macdonald, K.T. Liby, L. Mackenzie, D.W. Dales, B.D. Hedley, P.J. Foster, M.B. Sporn, A.F. Chambers, The synthetic triterpenoid CDDOImidazolide suppresses experimental liver metastasis, Clin. Exp. Metastasis 28 (2011) 309-317.

[219] X. Gao, D. Deeb, J. Hao, Y. Liu, A.S. Arbab, S.A. Dulchavsky, S.C. Gautam, Synthetic triterpenoids inhibit growth, induce apoptosis and suppress prosurvival Akt, mTOR and NF-\{kappa\}B signaling proteins in colorectal cancer cells, Anticancer Res. 30 (2010) 785-792.

[220] G.S. Subba Rao, P. Kondaiah, S.K. Singh, P. Ravanan, M.B. Sporn, Chemica modifications of natural triterpenes - glycyrrhetinic and boswellic acids: evaluation of their biological activity, Tetrahedron 64 (2008) 11541-11548.

[221] O.B. Kazakova, G.V. Giniyatullina, E.Y. Yamansarov, G.A. Tolstikov, Betulin and ursolic acid synthetic derivatives as inhibitors of Papilloma virus, Bioorg. Med. Chem. Lett. 20 (2010) 4088-4090.

[222] P. Wang, C. Li, J. Zang, N. Song, X. Zhang, Y. Li, Synthesis of two bidesmosidic ursolic acid saponins bearing a 2,3-branched trisaccharide residue, Carbohydr. Res. 340 (2005) 2086-2096. 